\title{
"Beyond the Source of Bioenergy": Microalgae in Modern Agriculture as a Biostimulant, Biofertilizer, and Anti-Abiotic Stress
}

\author{
Adewale Suraj Bello $^{1}\left(\mathbb{D}\right.$, Imen Saadaoui ${ }^{2}$ and $^{\mathbb{D}}$ adhouane Ben-Hamadou ${ }^{1, *(\mathbb{D})}$ \\ 1 Department of Biological and Environmental Sciences, College of Arts and Sciences, Qatar University, \\ Doha 2713, Qatar; a.suraj@qu.edu.qa \\ 2 Algal Technologies Program, Center for Sustainable Development, Qatar University, Doha 2713, Qatar; \\ imen.saadaoui@qu.edu.qa \\ * Correspondence: benhamadou@qu.edu.qa; Tel.: +974-44036454; Fax: +974-44034531
}

Citation: Bello, A.S.; Saadaoui, I.; Ben-Hamadou, R. "Beyond the Source of Bioenergy": Microalgae in Modern Agriculture as a Biostimulant, Biofertilizer, and Anti-Abiotic Stress. Agronomy 2021, 11, 1610. https://doi.org/10.3390/ agronomy11081610

Academic Editor: Danilo Scordia

Received: 21 June 2021

Accepted: 6 August 2021

Published: 13 August 2021

Publisher's Note: MDPI stays neutral with regard to jurisdictional claims in published maps and institutional affiliations.

Copyright: (c) 2021 by the authors. Licensee MDPI, Basel, Switzerland. This article is an open access article distributed under the terms and conditions of the Creative Commons Attribution (CC BY) license (https:// creativecommons.org/licenses/by/ $4.0 /)$.

\begin{abstract}
Microalgae are photoautotrophic organisms with high commercial potential. Extracts from microalgae are extensively used in crop cultivation, mainly because they possess growth-promoting properties, coupled with their enhancing impacts on the crop's ability to withstand abiotic stresses viz. extreme temperatures, drought, salinity, and mineral deficiency. The chemical composition of microalgae extract includes carbohydrates, proteins, lipids, vitamins, micronutrients, macronutrients, and phytohormones (auxins, cytokinins, ethylene, abscisic acid, and gibberellins). This review aims to provide an update on the trending facts for a better understanding of growing microalgae, the production of biomass, the processing of microalgae extracts, summarizing bioactive compounds, and the chemical constituent of microalgae extracts. Furthermore, we review the supporting literature on the application of microalgae extracts as biostimulants and biofertilizers to enhance crop productivity and control abiotic stresses in crop cultivation.
\end{abstract}

Keywords: abiotic stress; biofertilizer; biostimulant; extraction techniques; microalgae extract

\section{Introduction}

Algae are either aquatic when they live predominantly in water or subaerial when their existence, occurrence, or formation is on the surface of the earth rather than being found underwater. Thus, aquatic algae are microorganisms living in aquatic ecosystems such as freshwater, brackish water, spring, and salt lakes [1,2]. They can adapt to different levels of temperature, $\mathrm{pH}$, turbidity, Oxygen $\left(\mathrm{O}_{2}\right)$, and Carbon dioxide $\left(\mathrm{CO}_{2}\right)$ concentration. Generally, algae are classified based on their cell size and morphology. Based on the cell size, they are either microalgae $(0.8 \mu \mathrm{m}$ to $0.5 \mathrm{~mm})$ or macroalgae $(0.5 \mathrm{~mm}$ up to tens of meters) and could be unicellular when having a single cell or multicellular when having more than one cell. Additionally, when the classification is based on morphology, they either exist in a colonial or filamentous form [3,4]. When considering these traits, microalgae comprise one of the two main groups of algae studied in the literature. All algae are relatively cheap to produce and naturally embedded with rich nutrients and characterized by bioactive compounds such as plastids containing pigments viz. chlorophyll responsible for photosynthesis and light protection, fucoxanthin, and phycobiliproteins [5,6]. However, different strains of algae differ in the type of pigments they carry or are known for, as some have the chlorophyll (chl.) a molecule while others carry the combination of b or c, respectively, as illustrated in Table 1. 


\section{Biology of Microalgae}

The microalgae constitute a sizeable group made up of eukaryotic protists (photoautotrophs) as well as prokaryotic cyanobacteria. Generally, the prokaryotic group is classified into two divisions, namely Cyanophyta and Prochlorophyta, respectively. Similarly, there are nine eukaryotic divisions, which include Glaucophyta, Rhodophyta, Heterokontophyta, Haptophyta, Cryptophyta, Dinophyta, Euglenophyta, Chlorarachniophyta, and Chlorophyta [7].

Table 1. Characteristics of a few algal taxonomic classes.

\begin{tabular}{|c|c|c|c|c|c|c|c|c|c|c|}
\hline \multirow{2}{*}{$\begin{array}{l}\text { ALGAE } \\
\begin{array}{c}\text { Taxonomic } \\
\text { Class }\end{array}\end{array}$} & \multirow[b]{2}{*}{ Size } & \multicolumn{3}{|c|}{ Chlorophyll } & \multicolumn{2}{|c|}{ Other Pigments } & \multicolumn{3}{|c|}{ Organelle Characteristics } & \multirow[b]{2}{*}{$\begin{array}{c}\text { Storage } \\
\text { Product (s) }\end{array}$} \\
\hline & & a & $\mathbf{b}$ & c & Bili Protein & Carotenoids & Eukaryote & Mesokaryote & Prokaryote & \\
\hline Bacillariophyceae & 5-2000 $\mu \mathrm{m}$ & $\boldsymbol{v}$ & - & $\checkmark$ & Nil & $\begin{array}{l}\beta \text {-Carotene, } \\
\text { Fucoxanthin }\end{array}$ & $\boldsymbol{v}$ & $\checkmark$ & $\checkmark$ & $\begin{array}{l}\text { Lipids and } \\
\text { Chrysolami- } \\
\text { narin }\end{array}$ \\
\hline Charophyceae & $\begin{array}{l}\text { May exceed } \\
30 \mathrm{~cm} \text { in } \\
\text { length }\end{array}$ & $\checkmark$ & $\checkmark$ & - & Nil & $\begin{array}{l}\beta \text {-Carotene, } \\
\text { Zeaxanthin, } \\
\text { Lutein, } \\
\text { Violaxanthin, } \\
\text { Neoxanthin }\end{array}$ & $\checkmark$ & $\checkmark$ & $\checkmark$ & Starch \\
\hline Chlorophyceae & $10-80 \mu \mathrm{m}$ & $\checkmark$ & $\boldsymbol{v}$ & - & Phytochrome & $\begin{array}{l}\text { Zeaxanthin, } \\
\text { Lutein, } \\
\text { Violaxanthin, } \\
\text { Neoxanthin, } \\
\text { Loroxanthin. }\end{array}$ & $\checkmark$ & $\checkmark$ & $\checkmark$ & $\begin{array}{l}\text { Lipids and } \\
\text { Starch }\end{array}$ \\
\hline Chrysophyceae & $\begin{array}{l}\text { ca. } 2 \mu \mathrm{m}-\mathrm{ca} \text {. } \\
\quad 2 \mathrm{~mm}\end{array}$ & $\checkmark$ & - & $\checkmark$ & Nil & $\begin{array}{l}\beta \text {-Carotene, } \\
\text { fucoxanthin }\end{array}$ & $\boldsymbol{v}$ & $\checkmark$ & $\checkmark$ & $\begin{array}{l}\text { Lipids and } \\
\text { Chrysolami- } \\
\text { narin }\end{array}$ \\
\hline Cryptophyceae & $10-50 \mu \mathrm{m}$ & $\checkmark$ & - & $\checkmark$ & Phycoerythrin & $\begin{array}{c}\alpha \text {-Carotene, } \\
\text { Alloxanthin, } \\
\text { Crocoxanthin }\end{array}$ & $\checkmark$ & $\checkmark$ & $\checkmark$ & Starch \\
\hline Cyanophyceae & $\begin{array}{c}\text { Vary } \\
\text { considerably } \\
\text { in size }\end{array}$ & $\boldsymbol{v}$ & - & $\checkmark$ & $\begin{array}{l}\text { Allophycocyanin, } \\
\text { c-Phycocyanin }\end{array}$ & $\begin{array}{l}\text { Flavacene } \\
\beta \text {-Carotene, }\end{array}$ & - & - & $\checkmark$ & $\begin{array}{l}\text { Polyphosphate } \\
\text { Phycobilins }\end{array}$ \\
\hline Dinophyceae & $50-59 \mu \mathrm{m}$ & $\boldsymbol{v}$ & - & $\checkmark$ & Nil & $\begin{array}{c}\beta \text {-Carotene, } \\
\text { Diatoxanthin, } \\
\text { Monadoxan- } \\
\text { thin, } \\
\text { Dinoxanthin }\end{array}$ & - & $\checkmark$ & - & $\begin{array}{c}\text { Starch } \\
\text { (amylose or } \\
\text { amylopectin) }\end{array}$ \\
\hline Euglenophyceae & $\sim 35 \mu \mathrm{m}$ & $\checkmark$ & $\checkmark$ & - & Nil & $\begin{array}{c}\beta \text {-Carotene, } \\
\text { Diatoxanthin, } \\
\text { Diadinoxan- } \\
\text { thin, } \\
\text { Monadoxan- } \\
\text { thin } \\
\end{array}$ & - & $\checkmark$ & - & $\begin{array}{l}\text { Paramylon, } \\
\beta-1,3 \text { polymer } \\
\text { of glucose }\end{array}$ \\
\hline Haptophyceae & $3-7.5 \mu \mathrm{m}$ & $\checkmark$ & - & $\checkmark$ & Nil & $\begin{array}{c}\beta \text {-Carotene, } \\
\text { Diatoxanthin, } \\
\text { Diadinoxan- } \\
\text { thin, } \\
\text { Fucoxanthin }\end{array}$ & $\boldsymbol{v}$ & $\checkmark$ & $\checkmark$ & $\begin{array}{l}\text { Water-soluble } \\
1-3 \text { glucan } \\
\text { chrysolami- } \\
\text { narin }\end{array}$ \\
\hline Phaeophyceae & $\begin{array}{c}\text { Range of } \\
\text { morphologies } \\
\text { and sizes }\end{array}$ & $\checkmark$ & - & $\checkmark$ & Nil & $\begin{array}{l}\beta \text {-Carotene, } \\
\text { Fucoxanthin, } \\
\text { Violaxanthin }\end{array}$ & $\checkmark$ & $\checkmark$ & $\checkmark$ & $\begin{array}{l}\text { Luminaria, } \\
\text { Lipids }\end{array}$ \\
\hline Prasinophyceae & ca. $0.95 \mu \mathrm{m}$ & $\checkmark$ & $\boldsymbol{v}$ & - & Nil & $\begin{array}{c}\beta \text {-Carotene, } \\
\text { Micronone, } \\
\text { Neoxanthin, } \\
\text { Zeaxanthin, } \\
\text { Lutein, } \\
\text { Violaxanthin }\end{array}$ & $\checkmark$ & - & - & Starch \\
\hline
\end{tabular}


Table 1. Cont

\begin{tabular}{|c|c|c|c|c|c|c|c|c|c|c|}
\hline \multirow{2}{*}{$\begin{array}{l}\text { ALGAE } \\
\begin{array}{c}\text { Taxonomic } \\
\text { Class }\end{array}\end{array}$} & \multirow[b]{2}{*}{ Size } & \multicolumn{3}{|c|}{ Chlorophyll } & \multicolumn{2}{|c|}{ Other Pigments } & \multicolumn{3}{|c|}{ Organelle Characteristics } & \multirow[b]{2}{*}{$\begin{array}{l}\text { Storage } \\
\text { Product (s) }\end{array}$} \\
\hline & & a & b & c & Bili Protein & Carotenoids & Eukaryote & Mesokaryote & Prokaryote & \\
\hline Rhodophyceae & $\begin{array}{l}\underset{\sim 50 \mathrm{~cm}}{\operatorname{maximum}} \text { is } \\
\sim 50\end{array}$ & $\checkmark$ & - & - & $\begin{array}{l}\text { Allophycocyanin, } \\
\text { c-Phycocyanin, } \\
\text { Phytochrome }\end{array}$ & $\begin{array}{c}\beta \text {-Carotene, } \\
\text { Diatoxanthin, } \\
\text { Monadoxan- } \\
\text { thin, } \\
\text { Dinoxanthin }\end{array}$ & $\boldsymbol{v}$ & $\checkmark$ & $\checkmark$ & $\begin{array}{l}\text { Floridean } \\
\text { starch }\end{array}$ \\
\hline Xanthophyceae & $\begin{array}{c}\text { ca. } 2 \mu \mathrm{m} \text {-ca. } 2 \\
\mathrm{~mm}\end{array}$ & $\checkmark$ & - & $\checkmark$ & Nil & $\begin{array}{c}\beta \text {-Carotene, } \\
\text { Diatoxanthin, } \\
\text { Diadinoxan- } \\
\text { thin, } \\
\text { Heteroxan- } \\
\text { thin }\end{array}$ & $\checkmark$ & $\checkmark$ & $\checkmark$ & $\begin{array}{l}\text { Lipids, } \\
\text { chrysolami- } \\
\quad \text { narin. }\end{array}$ \\
\hline
\end{tabular}

Source: modified from Chapman, D, 1973, and Wehr, J.D. et al., 2015 [8,9].

This classification is based partly on the exhibited characteristics, namely pigmentation, the structure of the cell, and the life cycle. These algae are unicellular species that live individually or in chains or groups. Their sizes vary depending on the species; this can range from a single micrometer $(\mu \mathrm{m})$ to a hundred micrometers. They are different from higher plants because they lack roots, stems, and leaves. They mostly represent a noticeable subset of the group known as phytoplankton, of nearly 800,000 species are known, of which quite a sizeable number of species, approximately 50,000, have already been described by scientists [10]. Microalgae are organisms that can produce their food through photosynthesis, with feeding habits that are autotrophic, heterotrophic, or combining both as mixotrophic [11]. However, because they produce a huge number of different bioactive compounds suitable for biotechnological and clinical applications, microalgae production and their systems of cultivation have led to the serious involvement of scientists, researchers, and other stakeholders [12-14]. According to [15], microalgae biomass is a good input in the production of biofuels, biomaterials that comprise peptides, proteins, and saccharide polymers, and carbohydrates $\left(\mathrm{C}_{n}\left(\mathrm{H}_{2} \mathrm{O}\right)_{n}\right)$ for the livestock feed and human food sectors. Microalgae are photoautotrophs-microorganisms with the ability to make their food with the aid of radiant energy - that can grow in aquatic ecosystems (marine and freshwater environments) [16]. Aside from the aquatic ecosystem, they grow well in wastewater, minimizing the cost of production [17].

\section{Growing Microalgae}

\subsection{Growth Parameters}

The production of microalgae greatly depends on favorable cultivation conditions such as energy sources, carbon sources, reactor suitability, cost, large-scale application issues, biomass productivity $\left(\mathrm{g} \mathrm{L}^{-1}\right)$, highly productive microalgae species, as well as chemical constituents and luminous intensity [18]. The different species responded to each parameter differently, so it is vital to determine their specific optimal growth parameters $[19,20]$. However, the photosynthetic activities, cell biomass production, pathway, pattern, and cellular metabolism activities are greatly influenced by the environmental conditions / parameters, such as optimal temperature $\left(25-30{ }^{\circ} \mathrm{C}\right)$, sunshine intensity, air temperature during the day, and photoperiod, as well as the $\mathrm{pH}-7.5[18,20,21]$. Generally, most microalgae grow under various conditions of light that exhibit a different range from dark (heterotrophic) to light/luminous condition (phototrophic or mixotrophic). They thrive in saline water (seawater) and brackish water, as well as freshwater. Aside from these factors, other parameters such as the availability of nutrients and aeration are essential for the healthy and optimal growth of microalgae [22]. The general parameters for the optimal cultivation of microalgae [21] are shown in Table 2. 
Table 2. General factors for the cultivation of microalgae.

\begin{tabular}{|c|c|c|c|c|c|}
\hline Parameters & $\operatorname{Temp}{ }^{\circ} \mathrm{C}$ & Salinity $\left(\mathrm{g} \mathrm{L}^{-1}\right)$ & $\begin{array}{l}\text { Light Intensity } \\
\left(\mathrm{mmol} \mathrm{m}^{-2} \mathrm{~s}^{-1}\right)\end{array}$ & $\begin{array}{c}\text { Photoperiod } \\
\text { (Light: Dark, h) }\end{array}$ & $\mathrm{pH}$ \\
\hline Range & $16-27$ & $12.0-40$ & $\begin{array}{l}15-135 \text { (depends on } \\
\text { volume and density) }\end{array}$ & NR & $7.0-9.0$ \\
\hline Optimum & $18-24$ & $20-24$ & $40-70$ & $\begin{array}{l}\text { 16:8 (minimum) } \\
\text { 24:0 (maximum) }\end{array}$ & $8.2-8.7$ \\
\hline
\end{tabular}

Source: FAO, 2013.

\subsection{The Biochemical Constituent of Microalgae}

Microalgae biomass contains three main constituents, namely carbohydrates, proteins, and lipids. The composition of these biochemical components of different microalgae [23-26] is tabulated in Table 3. However, there is variation in the percentage of different constituents among the various microalgae, as the biochemical composition varies among microalgae species, or even when the species are the same under different growth conditions or life stage [27]. Considering the highly beneficial potential of fatty acids, they are a good basic material in the production of biodiesel. However, recently it was discovered that the benefits of microalgae are far greater than being a good raw material in the production of bioenergy $[27,28]$. Furthermore, the most abundant classes of microalgae when considering their distribution are Bacillariophyceae, Chlorophyceae, Cyanophyceae, and Chrysophyceae. However, aside from the biochemical composition, microalgae contain different molecules viz. amino acid compounds, pigments (e.g., chlorophylls, carotenoids, and anthocyanin), vitamins, hormones, and secondary metabolites which are valuable products that have good potential as a raw material in the cosmetic, food, biofuel, and pharmaceutical industries [29-31].

\subsection{Production Schemes}

Microalgae are considered one of the best organisms for protein production recombination, and are suitable for fine chemical production, pharmaceutical products, animal (e.g., poultry) feeds, feedstock, and essential basic material for the production of biofuels (biodiesels, bioethanol, hydrogen, as well as methane $\left(\mathrm{CH}_{4}\right)$ ). The cultivation of microalgae is relatively simple, with cheap growth conditions such as free water (blackish, fresh, sea), cheap nitrogen $(\mathrm{N})$, and phosphorus $(\mathrm{P})$, with a required light intensity to enhance the rate of growth [22,32]. Microalgae are regarded as a potential feedstock for both feed and food production. Nevertheless, technology has been yet to be fully developed to overcome the bottleneck for the optimal production of microalgae. Microalgae cultivation using human-made open ponds is technologically easy, but is not considered to be cheap because of the enormous processing cost required [33]. However, obtaining higher productivity and limiting production to monocultures resulted in the invention of enclosed tubular and flat-plate photobioreactors (PBRs) [22].

Table 3. Protein, carbohydrate, and lipid constituents' range of selected microalgae.

\begin{tabular}{ccccc}
\hline Algae & Carbohydrate (\%) & Lipid (\%) & Protein (\%) & References \\
\hline Arthrospira platensis & $8-20$ & $4-9$ & $49-65$ & {$[27,34]$} \\
\hline Chlorella species & $12-30$ & 10 & $30-35$ & {$[34-37]$} \\
\hline Scenedesmus species & $13-16$ & $12-14$ & $60-71$ & {$[34,37,38]$} \\
\hline Dunaliella species & $3-17$ & $14-21$ & $48-57$ & {$[27,34]$} \\
\hline Synechococcus species & $9-17$ & $14-55$ & $10-63$ & {$[34,38]$} \\
\hline
\end{tabular}


Table 3. Cont.

\begin{tabular}{ccccc}
\hline Algae & Carbohydrate (\%) & Lipid (\%) & Protein (\%) & References \\
\hline Euglena species & $14-18$ & $14-20$ & $39-61$ & {$[34]$} \\
\hline Prymnesium species & $14-18$ & $14-20$ & $39-61$ & {$[27,38]$} \\
\hline Anabaena species & $25-30$ & $9-14$ & $24-29$ & {$[27,35,38]$} \\
\hline Chlamydomonas species & $2-17$ & $9-21$ & $28-56$ & {$[27,34]$} \\
\hline Porphyridium species & $40-57$ & $9-14$ & $28-45$ & {$[27,38]$} \\
\hline Arthrospira maxima & $13-13$ & $6-7$ & $60-71$ & {$[27,34]$} \\
\hline Spirogyra porticalis & $33-64$ & $11-21$ & $6-20$ & {$[38]$} \\
\hline Tetraselmis maculata & 15 & 3 & 52 & {$[27,38]$} \\
\hline Pavlovaceae & $6-9$ & $9-14$ & $24-29$ & {$[34]$} \\
\hline
\end{tabular}

The higher biomass production and adequate regulation of culture factors under this system have not proved to be better than open pond cultures in terms of volumetric productivity or purity of biomass; however, the installation and operation cost of these systems is considered higher compared to open pond systems [22,33], along with the production cost. Unlike open pond cultures, photobioreactors are further hindered by the technical problems in decontaminating or purifying their components-therefore, their application is minimized in the production of high-value products such as pharmaceutical products [39]. Additionally, solar light availability is another common limitation, especially when the phototrophic culture method is used $[22,39,40]$. Recently, research, workshops, and training have been carried out and are still ongoing to develop optimum productive methodologies in the systems of production [22]. It is very necessary to develop a more reliable and ecofriendly technology to boost the production level, putting into cognizance the factors of production. The range of bioprocesses will enhance large-scale production after the careful selection of microalgae species. When the production targets are produced on a commercial or industrial scale, there are critical factors that need to be considered when developing the appropriate microalgae culture system. The factors include, but are not limited to, a high productivity area, high volumetric productivity, cost feasibility, an ability to control the environmental factors (temperature, carbon dioxide, turbidity, and $\mathrm{pH})$, low energy demand, and sustainability [41,42].

Microalgae cultivation is mostly associated with different systems of cultivation, ranging from outdoors to indoors. Practically, the dominant cultivation systems include the open raceway or racetrack ponds and closed bioreactors. These systems are operated often on a large and commercial scale, as enumerated graphically in Figure 1. 


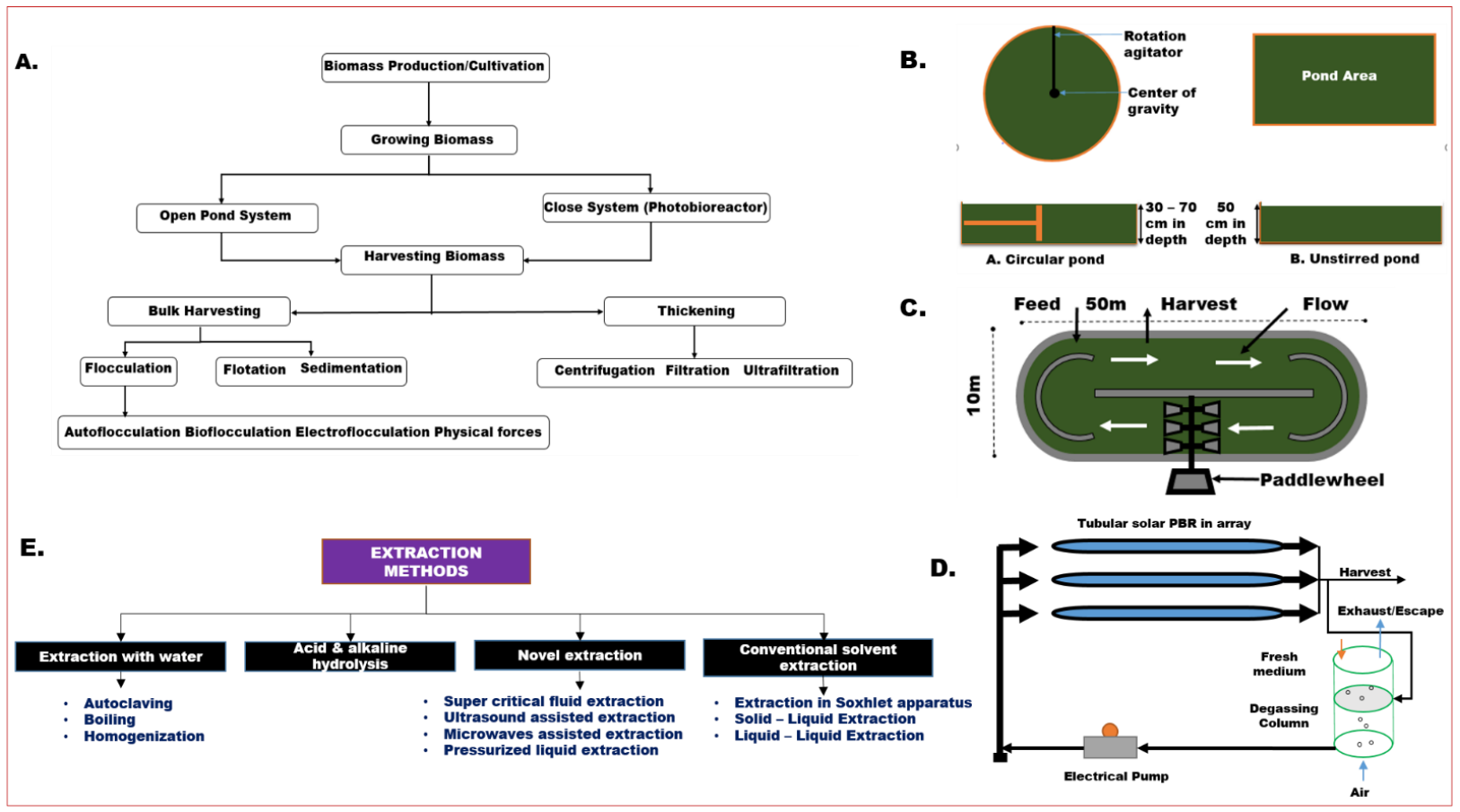

Figure 1. (A) Schematic of microalgae biomass production/cultivation; (B) types of open pond systems; (C) schematic raceway pond for microalgae cultivation; (D) schematic of solar-powered tubular PBR; (E) several techniques of production of microalgae extracts.

\subsubsection{Open Pond Systems}

Ponds are regarded as the most common open system for the industrial-scale production of microalgae (Figure 1B). Furthermore, the depth of such ponds, which might come in different shapes, generally does not exceeded $30 \mathrm{~cm}$. The nutrient and water circulation within the ponds is performed mechanically using an arm that rotates in a clockwise direction, which is particular to circular ponds, while a paddle is often used for stirring in other types of ponds, e.g., raceway $[22,43,44]$. There are two categories of this system, namely unstirred and circular ponds (Figure 1B). The unstirred open system is particular to a natural water source, and as a system, it lacks a stirred point. The cost is relatively cheap on the commercial scale, but mixing is very poor, which might lead to a lower output, ultimately. Plastic films can be used to cover the surface water to regulate temperature, as reported in previous studies [44-46]. In the case of circular ponds, they are predominantly employed in culturing the genera Chlorella, Arthrospira, and Dunaliella in most countries in Asia [39,44,47]. Unlike unstirred ponds, this type of pond has a long arm that rotates clockwise for proper mixing; the function of this arm is similar to that of the paddlewheels in the raceway pond. The output can range from 8.5 to $21 \mathrm{~g} \mathrm{~m}^{-2} \mathrm{~d}^{-1}[48,49]$. However, there are a few limitations associated with these systems; the controlling of temperature is almost impossible, which necessitates the need for an alternative source of heat supply. Additionally, predators, parasitic algae, as well as other strains with high viability can invade the pond, thereby dominating the wanted or needed species [22].

\subsubsection{Racetrack System}

The racetrack cultivation system is the most commonly adopted type of open system being used extensively and commercialized to produce algae on a large scale (Figure 1C), because it is easy to construct [22]. Some algae species showed high productivities using this system, such as Chlorella species, Dunaliella species, Haematococcus pluvialis, Arthrospira platensis. Usually, the racetrack pond is constructed with various dimensions in terms of breadth and length, but with a depth of approximately 15 to $50 \mathrm{~cm}$, and comprises either a single channel or a collection of channels. However, the ratio of the length to 
breadth is an important factor, as an extensive width may cause redundancy in the current speed, while an extensive length will cause the usage of a large land area [50,51]. However, paddlewheels are among the most important parts of raceway ponds, being essential for the controlling of liquid flow, meaning that the mixing of algae cells is homogenized and maximized to avoid unnecessary sedimentation in the configuration. The advantages of this configuration over other open types are that the entire production activities are very effective and easy, which makes it the first choice in large-scale commercial production using the outdoor type of production. In this system, the biomass outputs can be as much as $60-100 \mathrm{mg} \mathrm{L}^{-1} \mathrm{~d}^{-1}$ [52].

\subsubsection{Closed System (Photobioreactor)}

The photobioreactor (PBRs) is a closed system that prevents the enclosed microalgae from coming in contact with the prevailing environment (Figure 1D). The PBRs can be found outdoor sometimes; however, usually, they are located in the greenhouse, where the environmental factors can be regulated to maximize production [47,53-55]. The advancement in PBRs recently led to the mass production of algae, and this is necessary for feed and food grade, because algae must be produced free from any form of pollutant, including toxic metals and pathogenic microorganisms. This is important to meet the suitability requirements for the production of valuable products used as raw materials in the agricultural feed, pharmaceutical, and cosmetic industries $[52,55,56]$. The rate of evaporation is low, and $\mathrm{CO}_{2}$ emissions to the atmosphere are much lower with PBRs. There are different configurations associated with this system according to [55,57-59], such as (i) vertical column reactors (bubble columns or airlift); (ii) tubular reactors; and (iii) flat-plate reactors. Different studies described the efficacy of PBRs in the large-scale cultivation of microalgae at optimal level $[43,57,60]$.

However, the different types of PBR system were compared considering the essential factors that influenced the level of biomass productivity, as shown in Table 4. Additionally, Table 5 reveals the relationship that exists between open and closed systems based on the biomass output production coupled with the cost incurred related to expenditure and labor.

Table 4. The comparison of characteristics of the operating system under the open and close method.

\begin{tabular}{|c|c|c|c|c|c|}
\hline \multirow{2}{*}{ Characteristics } & \multirow{2}{*}{$\begin{array}{c}\begin{array}{c}\text { Open System } \\
\text { (Raceway) }\end{array} \\
\text { Paddlewheel }\end{array}$} & \multicolumn{3}{|c|}{ Closed System (Photobioreactor) } & \multirow{2}{*}{ References } \\
\hline & & Stirred Tank Reactor & Tubular Reactor & Column Reactor & \\
\hline Light use efficiency & Good & Good & Best & Good & {$[55,61]$} \\
\hline Transfer of gas & Normal & Lower-higher & Lower-higher & Higher & {$[12,62]$} \\
\hline Mixing potential & Partial uniformity & Nearly uniformity & $\begin{array}{l}\text { Perfect/absolute } \\
\text { mixing }\end{array}$ & Partial mixing & {$[54,63]$} \\
\hline Control of species & Nil & Best & Good & Good & {$[55,64]$} \\
\hline $\begin{array}{l}\text { Loss through } \\
\text { evaporation }\end{array}$ & High & Moderate & Nil & Nil & {$[61,65]$} \\
\hline Quality of biomass & Variable & Reproducible & Reproducible & Reproducible & {$[54,57]$} \\
\hline $\begin{array}{l}\text { Energy demand for } \\
\text { mixing }\end{array}$ & Low & High & High & High & {$[64,66,67]$} \\
\hline Maintenance & Easy & Difficult & Difficult & Difficult & {$[62,64,67]$} \\
\hline Required space & Large area & Moderate & Moderate & Moderate & {$[54,57,63]$} \\
\hline Type of operation & Batch & Batch & Batch & Batch & {$[54,65,67]$} \\
\hline Setup capital & Low & High & High & High & {$[64,67]$} \\
\hline Limitations & $\begin{array}{l}\text { Requires a huge } \\
\text { area of land }\end{array}$ & $\begin{array}{l}\text { Requires large setup } \\
\text { capital }\end{array}$ & $\begin{array}{l}\text { Possible formation of } \\
\text { fouling/scale along } \\
\text { the bend regions }\end{array}$ & $\begin{array}{l}\text { High } \\
\text { maintenance cost }\end{array}$ & {$[64,66,67]$} \\
\hline
\end{tabular}


Table 5. Comparison of different methods of microalgae cultivation and cost of production.

\begin{tabular}{|c|c|c|c|c|c|c|}
\hline $\begin{array}{l}\text { Production } \\
\text { Technology } \\
\text { (USD) }\end{array}$ & $\begin{array}{l}\text { Capital Costs } \\
\text { kg }^{-1} \text { (USD) }\end{array}$ & $\begin{array}{l}\text { Labour kg }{ }^{-1} \\
\text { (USD) }\end{array}$ & $\begin{array}{c}\text { Other Variable } \\
\text { Costs (Utilities, } \\
\text { Fertilizer) } \text { kg }^{-1} \\
\text { (USD) }\end{array}$ & $\begin{array}{c}\text { Total Costs/kg } \\
\text { for a Large (100 } \\
\text { ha-200 ha) Plant } \\
\text { (USD) }\end{array}$ & $\begin{array}{l}\text { Optimal } \\
\text { Theoretical Total } \\
\text { Costs } \text { kg }^{-1} \text { Dry } \\
\text { Weight (USD) }\end{array}$ & References \\
\hline \multirow{3}{*}{ Open ponds } & \multirow{3}{*}{3.58} & \multirow{3}{*}{0.18} & \multirow{3}{*}{1.86} & $\begin{array}{c}25(2004) \\
7.07\end{array}$ & 0.81 & \multirow{3}{*}[43,68,69]{} \\
\hline & & & & 5.87 & 0.25 & \\
\hline & & & & $8-11$ & & \\
\hline \multirow{2}{*}{$\begin{array}{l}\text { Horizontal } \\
\text { tubular PBR }\end{array}$} & 3.25 & 1.04 & 1.09 & 4.92 & \multirow{2}{*}{ (NA) } & \multirow{2}{*}[68,69]{} \\
\hline & 11.63 & 0.43 & 1.96 & 14.95 & & \\
\hline Flat panel PBR & 12.38 & 0.42 & 1.20 & 7.07 & 2.14 & [68-70] \\
\hline
\end{tabular}

Source: modified from Enzing et al., 2014. Figures for 2010/2011. PBR = photobioreactor, NA = not available.

\section{Microalgae-Derived Extracts (Bioactive Compound and High-Value Product)}

The derived extracts (bioactive and high-value products) from microalgae are categorized based on their physicochemical properties and their bioactivities (e.g., antifungal, antibacterial, antiviral, anti-inflammatory, etc.). The extraction method and the nature of the solvent's influence are strictly dependent on nature and the quality of the bioactive molecule, presenting an impact on its associated application. Microalgae have several beneficial properties aside from being a source of biogas. They have gained wide acceptance for agricultural applications because of their embedded bioactive compounds that enhance plant productivity. Such bioactive compounds include carbohydrates, minerals, and trace elements, growth hormones (cytokinins, auxins, and auxin-like compounds), betaines, and sterols [71,72]. Additionally, they are widely gaining global acceptance as a raw material in the production of animal feed additives, cosmetics, pharmaceuticals, biofuels, plant growth promoters, and medicines, and for mitigating abiotic stress and preventing pollution $[12,28,73-77]$.

\subsection{Extraction Methods of Microalgae Extract}

The different methods often used in the microalgae extract were explained extensively in several studies and the literature [72,78].

The important first step in the extraction is the rupture of a cell by wall extraction methods to release the bioactive substances $[78,79]$. The most common methods include, but are not limited to, the following, as shown in Figure 1E.

Extraction with water is a mechanical or physical method using such techniques as autoclaving, boiling, and homogenization to disrupt the cell wall of the microalgae as a pretreatment to release the bioactive compounds in the liquid medium. These types of techniques are considered to be among the traditional, less expensive methods, but require more energy. Acid and alkaline hydrolysis is a chemical method that uses different types of chemicals to disrupt microalgae cell walls. The most prominent chemicals in use are sodium hydroxide $(\mathrm{NaOH})$, hydrochloric acid $(\mathrm{HCl})$, hydrogen tetraoxosulphate (VI) acid $\left(\mathrm{H}_{2} \mathrm{SO}_{4}\right)$, nitrous acid $\left(\mathrm{HNO}_{2}\right)$. On the other hand, conventional solvent extraction is considered a traditional method that operates in three different mediums viz. the Soxhlet apparatus, the solid-liquid, and the liquid-liquid extraction method. However, hydrophobic solvents such as petroleum ether, aromatic compounds, hexane, cyclohexane, chloroform, acetone, dichloromethane, and alcohols, e.g., ethanol, methanol, etc., have been the most commonly used solvents in most outstanding extraction methods [80,81]. Nevertheless, the Soxhlet apparatus has taken over as the most reliable method, and is often used in extraction processes because of its advantages of easy operation, safety, and scaleup being possible at all times [82]. Using solvent methods of extraction in the extraction of the bioactive compounds from microalgae requires the use of greater volumes of solvents, consumed in longer extraction processes. Not only that, but the output is also considerably 
low. However, the existing novel extraction techniques (NET) viz. supercritical fluid extraction (SFE), microwave-assisted extraction (MAE), ultrasound-assisted extraction (UAE), enzyme-assisted extraction (EAE), and pressurized liquid extraction (PLE) provide an improvement over the other extraction methods and as a better substitute because of their various disadvantages. NET is more efficient, less time-consuming, cost-efficient, and environmentally safe $[83,84]$.

\subsubsection{Novel Techniques of Extraction}

The emergence of different state-of-the-art extraction methods has exhibited the ability to handle and solve the common drawbacks that are particular to the traditional methods of extraction. Among them are SFE, PLE, MAE, UAE, and EAE, respectively. These methods have been considered as the best alternative to the traditional methods. Therefore, these techniques are further elaborated to reflect their potential value in the extraction of bioactive compounds from marine algae.

\section{Supercritical Fluid Extraction (SFE)}

SFE is considered a widely accepted green extraction technology based on solvent utilization that exceeds their critical pressure as well as temperature [85-87]. SFE technology has been used before to extract numerous types of important compound from all kinds of food-related items, as well as algae species [88,89]. This technology is particularly known for its different valuable benefits, and one of them is the use of a reasonably reduced amount of toxic hydrophobic solvents. Thus, the most frequently used solvent in SEF is carbon dioxide $\left(\mathrm{CO}_{2}\right)$ to extract bioactive compounds from their natural source. Using $\mathrm{CO}_{2}$ as an extraction solvent in SFE is beneficial because of its specific properties viz. cost efficiency, the easy attainment of its critical conditions of temperature and pressure $\left(30.9^{\circ} \mathrm{C}\right.$ and 73.8 bars), and being an environmentally friendly solvent widely used in human and animal food industry because it has been generally recognized as safe (GRAS) [83], as well as the pharmaceutical, pesticide, and fuel industries [84], respectively. SFE technology was first reported in 1879 for extraction purposes by Hanny and Hogarth [90], but is gaining widespread acceptance in industries and research because of the technological advancements attained in the SFE methodology [91,92]. A basic scheme of an SFE system is shown in Figure 2 to further illustrate this unique technique.

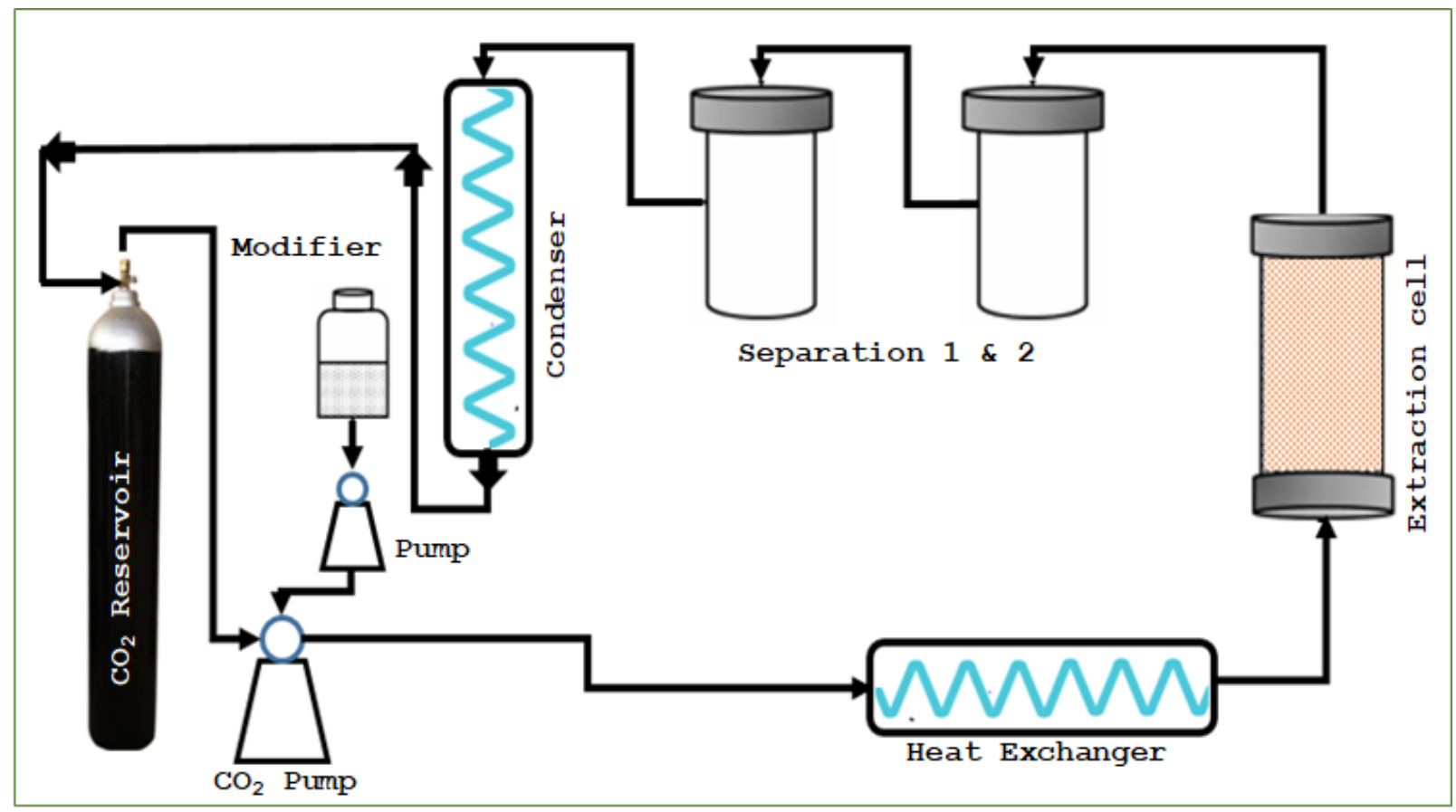

Figure 2. Illustrative diagram of supercritical fluid extraction (SFE). 


\section{Pressurized Liquid Extraction (PLE)}

PLE technology came to the limelight in 1996 when it was reported by BE Richter et al. [93]. The technology behind PLE is simply the application of pressure to permit the utilization of liquids at temperatures that well exceed their actual boiling point. This technology is also known by other names such as pressurized fluid extraction (PFE), enhanced solvent extraction (ESE), high-pressure solvent extraction (HPSE), and accelerated solvent extraction (ASE) [94]. The combination of high pressures and temperatures in PLE leads to faster extraction activities that need small amounts of solvents. A good example of this is a comparison of using 10-50 cc of solvent for 20 min in PLE with a traditional extraction method in which up to $300 \mathrm{cc}$ of solvent for $10-48 \mathrm{~h}$ is required, and thus PLE proved to be more efficient due to this phenomenon, as further illustrated by a basic illustrative diagram of a PLE methodology in Figure 3. Interestingly, when the extraction temperature increases, the analyte solubility is likely to be higher by increasing the solubility, as well as transfer rate simultaneously [83]. However, PLE is characterized by low hydrophobic solvent consumption, which gives PLE wide acceptance and broad recognition. One of the drawbacks of PLE is its nonsuitability for thermolabile compounds prone to excessive temperature, as well as pressure conditions. Nonetheless, the use of PLE for the extraction of bioactive compounds from brown macroalgae and microalgae has been investigated and documented by several studies $[95,96]$.

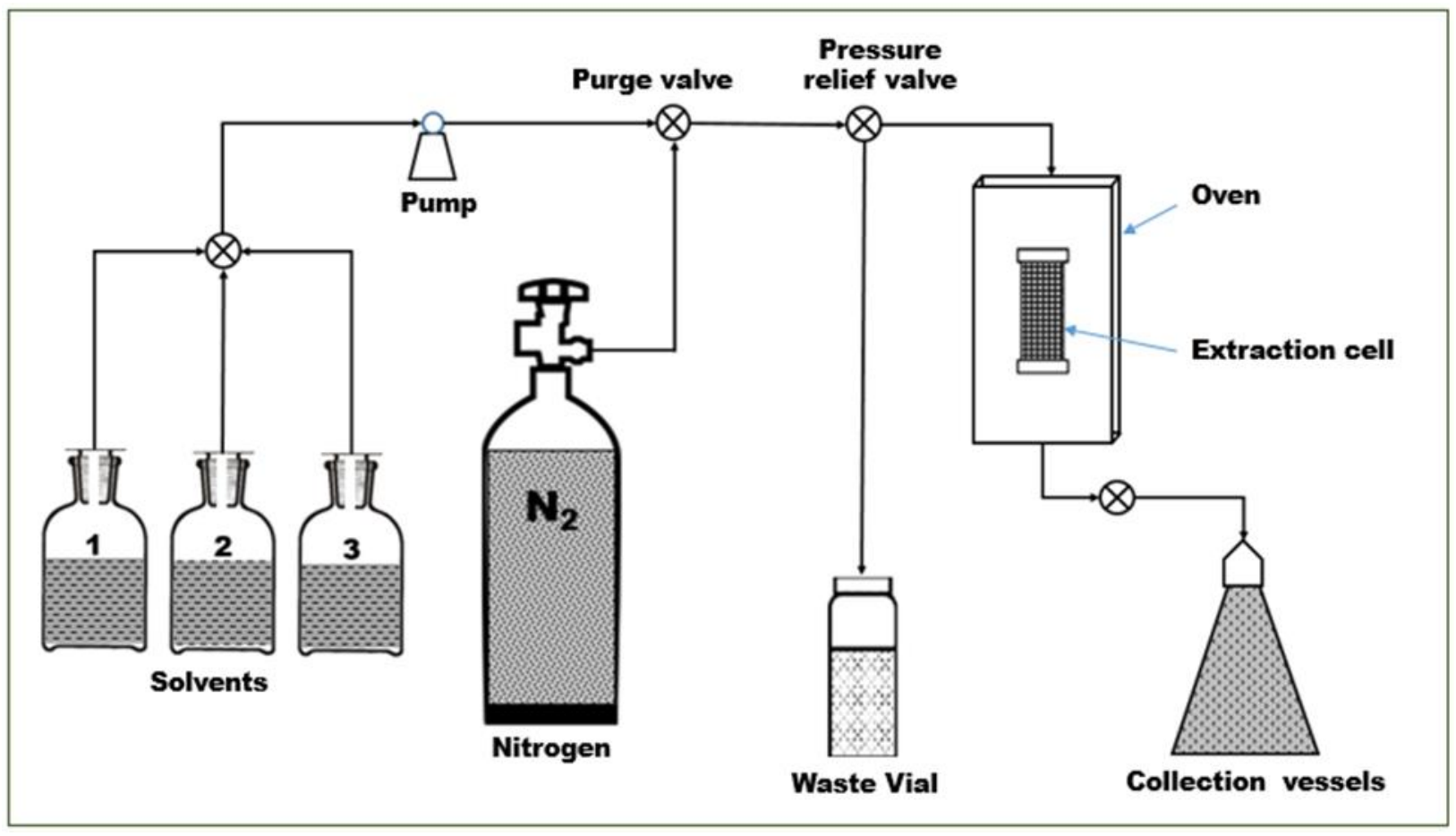

Figure 3. Illustrative diagram of pressurized liquid extraction (PLE).

Microwave-Assisted Extraction (MAE)

MAE is another green technique that was first reported in 1986 for the extraction of different compounds [97]. MAE uses electromagnetic radiation with frequencies that range from $10^{9} \mathrm{~Hz}$ (1 gigahertz-1 GHz) to $1000 \mathrm{GHz}$, with corresponding wavelengths of $3.0 \times 10^{1}$ to $3.0 \times 10^{-2} \mathrm{~cm}$, respectively [98]. Considering the MAE technique, microwaves induce the vibration of polar molecules and the movement of dipoles to increase the temperature of solvents in order to facilitate the transferring of the active compound from the sample matrix into the solution [83,99]. During the process, the breaking of hydrogen bonds is accomplished and the penetration of solvents into the sample matrix increases because of the movement of dissolved ions, thus influencing the extraction of 
target compounds [100]. Interestingly, from several studies, it has been established that in terms of economic feasibility, MAE is a better choice compared to SEF, which is more costly to operate [80]. However, the extraction of bioactive compounds from algae using MAE techniques was successfully documented and reported in the literature. Such compounds include docosahexaenoic acid, fucoidan, pigment (fucoxanthin), phenols, polysaccharides, and phytosterols, etc. [101-106].

\section{Ultrasound-Assisted Extraction (UAE)}

$\mathrm{UAE}$ as a green technology uses sound waves that travel via the medium and subsequently cause pressure variation within the system [80]. Thus, the produced acoustic cavitations induce the cell wall disruption, curtailment of the size of the particles, and strengthening of the interaction between the solvent and the active compounds being targeted [83]. UAE is often used as a reliable method to pretreat the potential biomass before the extraction proper, which is commonly executed with either of the two types of ultrasound equipment, namely an ultrasonic bath or ultrasound/ultrasonic probe instrument [107], as illustrated in Figure 4. The use of both UAE and MAE methods simultaneously is sometimes possible, because both of them are very flexible as a result of their tendency to use several solvents that are characterized by different polarities; interestingly, both can perform extraction and reaction concurrently [83,84]. In a study conducted by Cravotto et al. [101], a combined methodology using both UAE and MAE simultaneously for oil (rich in DHA) extraction from a species of dinoflagellate microalgae Crypthecodinium cohnii [80] was employed. The common benefits of UAE and MAE technologies either being used individually or combined have the potential to greatly improve the rate of extraction, output, and cost reduction compared to the traditional extraction process [84]. The extraction of pigments such as carotenoids (lutein), as well as chlorophyll-a from aquatic macroalgae and microalgae, has been accomplished with the use of UAE recently $[83,84]$.

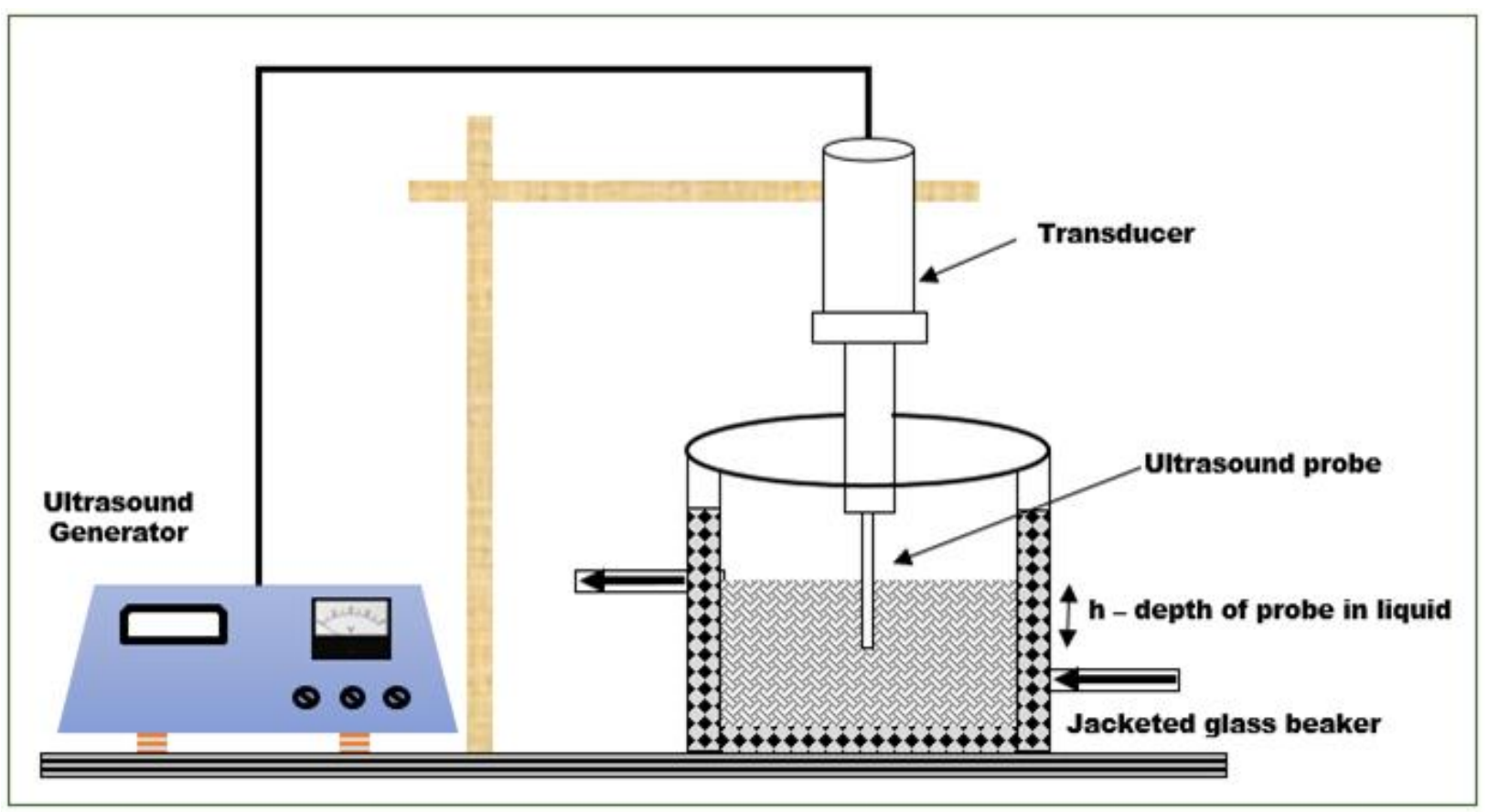

Figure 4. Illustrative diagram of ultrasound-assisted extraction (UAE). 
Enzyme-Assisted Extraction (EAE)

As the name implies, this entails the use of cell wall-degradable enzymes viz. carbohydrases, as well as proteases to crack down the cell wall of the marine algae that is characterized as being chemically complex and structurally heterogeneous compared to normal cells (e.g., animal and plant cells) [108], thus enhancing the process of extracting biologically active substances from the marine algae [108]. However, to obtain good output, most especially as related to the quality, coupled with the prevention of possible degradation of the biologically active substance, EAE should be conducted at the optimal temperature and $\mathrm{pH}$. Interestingly, the compiled list of enzymes and their favorable conditions needed for the optimum production of bioactive compounds from marine algae when applying the EAE method was well documented in the study of Kadam et al. [84]. Additionally, a similar study carried out by Liang et al. [109] compiled and reported the lists of enzymes used during the extraction of lipids from microalgae when the enzyme-assisted aqueous extraction method is employed. The frequently used enzymes include, but are not limited to, Viscozyme, Cellucast, Termamyl, Ultraflo, carragenanase, agarase, xylanase, Kojizyme, Neutrase, Alcalase, and Umamizyme [84].

\subsection{Chemical Constituents of Microalgae Extracts}

Microalgae extract can generate a reasonable quantity of biologically active primary and secondary metabolites. In the work of Puglisi et al., 2018, it was reported that the extraction methods or techniques applied, as well as the microalgae species used in extraction process may have a great influence on the output and the quality of bioactive compounds obtainable from microalgae extract [110]. The primary bioactive metabolites are made up of carbohydrates, proteins, lipids, and vitamins. However, as summarized in Table 3, the quantities of these important biochemical components significantly vary among the microalga species, as well as within the same species. In particular, these variations are likely to be connected with the impacts of numerous biotic and abiotic parameters viz. cultivation under favorable as well as optimal conditions, seasonal variability, nutrient availability, and so forth.

Carbohydrates constitute the most essential component of microalgae extract. The composition of carbohydrates ranges between $3 \%$ and $40 \%$ or more. In the common species, the composition of carbohydrates are found in Chlorella spp. (9.42-15.5\%), Chlamydomonas sp. (3.28\%), Dunaliella sp. (21.69\%), and Arthrospira sp. (12-30.21\%), Cladophora glomerata (34.7\%), Dunaliella tertiolecta (21.69\%), Schizochytrium limacinum (24\%) [111-116]. Meanwhile lipids may account for as much as $50 \%$ of the dry weight (DW) of the microalgae extract, as found in Chlorella spp. $2.5 \%$, Chlamydomonas spp. (12.19\%), Dunaliella sp. (2.87\%), and Arthrospira sp. (10.3\%), Cladophora glomerata (5.8\%), Dunaliella tertiolecta $(2.87 \%)$, Schizochytrium limacinum (51\%). Furthermore, proteins constitute approximately $18-46 \%$ (DW) or even higher in some cases in various species of the microalgae-generated extract [117]. Among the various amino acid classes, tryptophan present in microalgae extracts, as well as arginine, exhibited significantly high potential enhancement characteristics on the cultivated plant growth, development, and output, as these two amino acids play vital roles, being antecedent to essential signal molecules known mostly as secretory and non-secretory peptides [118-120]. Among the amino acids, tryptophan play a key role in plant metabolism activities, as it is responsible for protein formation, and is the forbearer of plant hormones viz. auxin, gibberellin, salicylic, as well as arene secondary compounds that have different biological functions $[79,120]$.

\subsection{Application Methods of Microalgae Extracts}

There are several methods by which microalgae extracts (high-value products) are applied to crops, either as biostimulants or as biofertilizers, which are understudied. Such methods include, but are not limited to, foliar spray or application, which entails direct fertilization through a plant's leaves, contrary to applying through the soil. Additionally, soil fertilization is the most common method of applying fertilizers/nutrients to plants 
through the soil to improve the soil's fertility, thus enhancing the growth performance of such plants, while the hydroponics system is a method of applying nutrients in the form of a fertilizer to the crop without soil. Microalgae extracts are used extensively as microalgae products on agronomic, ornamental, and horticultural crops, existing in two forms, namely in liquid/aqueous form or in liquid-soluble powder form [121,122]. The extracts could be applied in powder form as a biomass for soil amendment. In another way, the liquid extract is sometimes applied directly to the targeted root system of the plant, as the mixture is prepared by thoroughly mixing the required dose of the extract into irrigation water using different types of irrigation system, e.g., a drip system to crops [79]. Microalgae extracts are mostly used as a foliar spray on different cereal crops, vegetables, a variety of flowers, and tree species viz. aubergine (Solanum melongena L.), garlic (Allium sativum), pepper (Capsicum sp.), tomato (Solanum lycopersicum L), and petunia (Petunia $\times$ atkinsiana) [123-126]. As with any other crop, foliar application of microalgae extracts was found to exhibit higher performance when applied during the morning, as the stomata of the leaves are wide open, and when relative humidity conditions are high, as the product uptake and permeability rise [127].

\section{Microalgae Extracts as Biostimulant and Biofertilizer}

Microalgae extracts are derivative products with beneficial potential in modern agriculture, ranging from nutrient uptake enhancement to crop efficiency improvement, nutrient loss prevention, physiological status improvement, and abiotic stress addressor [128,129]. Furthermore, microalgae's potential has not been fully exploited by plant scientists in the field of agronomy and crop science, despite their ability to produce biologically active substances that have enhancement properties on crop production [128,130,131]. Experimental studies were conducted to test the impact of microalgae extract as a biostimulant and biofertilizer under different cultivation conditions viz. open field, greenhouse, and hydroponics on different crops such as cereals, vegetables, medicinal crops, etc., exhibiting positive impacts. They displayed the ability to sustain agricultural productivity and minimize environmental degradation [125,132-135].

As of late, exploratory investigations testing the activity of microalgae extracts under open-field cultivation, growth chamber, and greenhouse conditions have exhibited their potential to invigorate germination and the development of seedlings, shoots, and root systems in vegetable and cereals, etc. [125,136,137], as shown in Table 6. Such crops include, but are not limited to, radish, cabbage, lettuce, red amaranth, pak choi, tomato, pepper, wheat, and rice [136-139]. Table 6 revealed several studies testing the morphological and molecular responses resulting from the application of microalgae extracts from various species on different crops such as lettuce, tomato, pepper (Capsicum annuum), pak choi, red amaranth, and other crops.

Lettuce (Lactuca sativa L.) grown in soil inside a greenhouse was fertilized twice using a fresh and dried extract of Chlorella vulgaris. Doses of $0.5,1,2$, and $3 \mathrm{~g}$ fresh and dried algal cells were applied per $1 \mathrm{~kg}$ of soil. The factors (agronomic and physiological responses) measured, including chlorophyll a, b, carotenoids, and growth factors (root dry weight and length), displayed positive results compared with the control at the various doses. The most significant results were obtained at the higher treatments of 2 and $3 \mathrm{~g}$ of dry biomass per $1 \mathrm{~kg}$ of soil, respectively [138]. In a similar study, extracts from Chlorella vulgaris and Scenedesmus quadricanda were applied to sugar beet (Betavulgaris L. sp. vulgaris) to investigate its morphological and molecular responses to different treatments. Sugar beet seedlings were cultivated hydroponically using Hoagland solution in a regulated environment. The application of extracts from Chlorella vulgaris and Scenedesmus quadricanda were applied at two different doses of 2 and $4 \mathrm{~mL} \mathrm{~L}^{-1}$ after five days [139]. After $36 \mathrm{~h}$, the morphological response was positive, as the treated seedlings displayed greater root length, root surface, and number of root tips when compared with the control. The molecular analysis revealed the upregulation of some genes related to biological pathways and activities, with primary and secondary metabolism and nutrient movement within the cells, 
particularly relating to root traits that have to do with nutrient absorption [139]. In addition, Garcia-Gonzalez et al., 2016 studied the effect of Acutodesmus dimorphus aqueous cell extract as a biofertilizer on tomato (Solanum lycopersicum L.) under greenhouse conditions using Petri dishes. The treatments were carried out as seed primer and foliar applications at various concentrations $\left(0,0.75,1.875,3.75,5.625\right.$, and $\left.7.5 \mathrm{~g} \mathrm{~mL}^{-1}\right)$ of aqueous cell extracts. The treated seeds exhibited a higher germination rate, significant plant growth, and floral production compared to the negative control [125]. In the study conducted by Shariatmadari et al., 2013, the effect of Anabaena vaginicola ISC90 and Nostoc calcicola ISC89 extracts in potted plants under greenhouse conditions was tested to investigate their effects on the morphological parameters of vegetable crops viz. Cucurbita maxima Duch. ex Lam. (Squash: UG 5206 F1), Cucumis sativus L. (Cucumber: E 32.15720 F1), and Solanum lycopersicum L. (Tomato: E $26.32365 \mathrm{~F} 1$ ). Spraying the extract on the soil at 7-day intervals with extract of Anabaena vaginicola ISC90 and Nostoc calcicola ISC89 enhanced the plant height, root length, dry weight, fresh weight, and the number of leaves for tomato after 40 days of experiments [140]. Dmytryk et al., 2014 studied the effect of Arthrospira plantensis extract treatments on wheat seeds in Petri plates at different concentrations. The seeds were coated with three doses $(8,14$, and $20 \mu \mathrm{L} / 1 \mathrm{~g}$ of seeds, respectively) and were compared with an untreated control. The treated and control seeds were grown in a cotton base in nine replicates of each sample for 11 days. The seeds coated with the extract exhibited an increase in biomass yield of nearly $13 \%$ compared to the untreated seeds. However, the seeds coated with $8.0 \mu \mathrm{L} \mathrm{g}^{-1}$ gave the best results [141]. The study conducted by Michalak et al., 2016 on the field trial of the effect of fluid extraction and whole biomass of Arthrospira plantensis on wheat showed a positive response. It was found that the number of grains per ear and shank length were highest compared to the control group at a dose of $1.5 \mathrm{~L} \mathrm{ha}^{-1}$ [72]. In a similar study, Mahmoud A. Saman et al., 2015 reported that the application of Laurencia obtuse and Corallina elongate powder (biomass) enhanced the antioxidant and phytochemical constituents of maize (Zea mays. L) [142]. There was a tremendous improvement in the root, polyphenolic, and antioxidant contents. With the application of Janiarubens ( $3 \mathrm{~g}$ powder $/ \mathrm{kg}$ soil), the nitrogen content and protein content of the whole plant increased by $129.2 \%$, while the application of Coralline elongate at the same dose gave the best results in increasing the polyphenolic and antioxidant contents of the shoot, as well as the tannic acid content of the root [142]. El-Eslamboly et al., 2019 recorded the extracts of Arthrospira plantensis and Amphora cofeaeformis as being valuable applications, as they boosted/enhanced vegetative growth, yield, fruit quality, and nematode control in cucumber. There was a 2.5 and 2.69 double increment in marketable output compared with the control group when treated with Amphora cofeaeformis [143]. Additionally, Figure 5 shows the importance of the final products from the extraction process, as they enhance nutrient intake improvement, increase the quality of the product, and improve abiotic stresses tolerance. 
Table 6. The morphological and molecular responses resulting from the application of microalgae in high-value products and whole biomass from various microalgae species.

\begin{tabular}{|c|c|c|c|c|c|c|}
\hline Crop & Greenhouse & M/Species & Extraction/Process Method & Conc. Of AE & Parameters & Reference \\
\hline Lettuce & Soil & Chlorella vulgaris & $\begin{array}{l}\text { Fresh and dried algal were applied in the } \\
\text { field to vegetables }\end{array}$ & $\begin{array}{c}\text { Biofertilizer-1/2, } 1,2 \text {, and } 3 \mathrm{~g} \text { of fresh } \\
\text { algal and dry algal cells } / 1 \mathrm{~kg} \text { soil } \\
\text { Biomass }\end{array}$ & $\begin{array}{c}\text { Chlorophyll } \mathrm{a}, \mathrm{b} \text {, and carotenoids. } \\
\text { Plant growth (root dry wt. and } \\
\text { length) }\end{array}$ & [138] \\
\hline Tomato & Petri plates & Acutodesmus dimorphus & $\begin{array}{c}1 \mathrm{~kg} \text { of biomass freeze dried submerged in } \\
\text { distilled water, DW }\left(\text { Conc. } 150 \mathrm{~g} \mathrm{~L}^{-1}\right)= \\
\text { the suspension + micro fluidizer } \\
(\mathrm{M}-110 \mathrm{EH}-30)=\text { intracellular extract. } \\
\text { Intracellular extract }+ \text { centrifugation } \\
\left(8989 \times \mathrm{g} / 10 \mathrm{~min} / 22^{\circ} \mathrm{C}\right) \text {. The collected } \\
\text { supernatant in a flask covered with foil } \\
\text { paper to reduce potential degradation was } \\
\text { stored at } 4{ }^{\circ} \mathrm{C}\end{array}$ & $\begin{array}{c}\text { Seed primers-different } \\
\text { concentrations }(0,1,5,10,25,50,75 \\
\text { and } 100 \%) \text { of aqueous cell extracts } \\
\text { from DW OR } \\
10 \mathrm{~mL}, 0.1 / 9.9 \mathrm{~mL}, 0.5 / 9.5 \mathrm{~mL} \\
1 / 9 \mathrm{~mL}, 2.5 / 7.5 \mathrm{~mL}, 5 / 7.5 \mathrm{~mL}, 7.5 / 2.5 \\
\mathrm{~mL}, 10 \mathrm{~mL}\end{array}$ & $\begin{array}{l}\text { Seed germination, germination } \\
\text { energy, lateral root development, } \\
\text { flower development }\end{array}$ & [125] \\
\hline $\begin{array}{c}3 \text { types of } \\
\text { vegetable-Chinese } \\
\text { Cabbage, } \\
\text { Chinese broccoli, and } \\
\text { Protea White Crown. }\end{array}$ & Tissue towel & Arthrospira platensis & $\begin{array}{l}\text { A desirable quantity of microalgae } \\
\text { suspension ( } 50 \mathrm{~mL} \text { ) was removed from } \\
\text { growing flasks and then allowed to pass } \\
\text { through centrifugation for a maximum of } \\
10 \text { min. The collected supernatants were } \\
\text { examined to determine the level of } \\
\text { ammonia, nitrate, and nitrite }\end{array}$ & $\begin{array}{c}\text { Biofertilizer-seed germination } \\
\text { study-Arthrospira biomass. T1 to T5, } \\
\text { T0 (tap water only). }(2,4,6,8 \text {, and } \\
10 \mathrm{~g} \mathrm{~L}^{-1} \text {, respectively) } \\
\text { biomass }\end{array}$ & $\begin{array}{l}\text { Rate of germination, root and shoot } \\
\text { length, vigor index as well as dry } \\
\text { weight of } 100 \text { seedlings }\end{array}$ & [144] \\
\hline $\begin{array}{l}\text { Arugula, Bayam Red, } \\
\text { and Pak Choy plants }\end{array}$ & $\begin{array}{l}\text { Potted plants } \\
\text { experiment }\end{array}$ & Arthrospira platensis & $\begin{array}{l}\text { A desirable quantity of microalgae } \\
\text { suspension }(50 \mathrm{~mL}) \text { was removed from } \\
\text { growing flasks. Then, it was allowed to } \\
\text { pass through centrifugation for a } \\
\text { maximum of } 10 \text { min. The collected } \\
\text { supernatants were examined to determine } \\
\text { the level of ammonia, nitrate, and nitrite }\end{array}$ & $\begin{array}{l}\text { Biofertilizer-potted plants and } \\
\text { control-Arthrospira platensis }(5 \mathrm{~g} / 500 \\
\text { g soil), inorganic fertilizer-Triple Pro } \\
15 / 15 / 15\left(3 \times 10^{-1} \mathrm{~g} / 500 \mathrm{~g}\right. \\
\text { soil/week). Additionally, Arthrospira } \\
\text { platensis + inorganic fertilizer } \\
\left(3 \times 10^{-1} \mathrm{~g} / \text { pot/week) biomass }\right.\end{array}$ & $\begin{array}{l}\text { Weekly measurement of plant } \\
\text { growth (plant height and number of } \\
\text { leaves per plant). After the } \\
\text { completion of the experiment, } \\
\text { parameters such as the number of } \\
\text { leaves, the height of the plant, } \\
\text { chlorophyll content, length of root, } \\
\text { fresh, as well dry weights were } \\
\text { determined. }\end{array}$ & [144] \\
\hline Tomato & $\begin{array}{l}\text { Potted plants } \\
\text { experiment }\end{array}$ & $\begin{array}{l}\text { Anabaena vaginicola ISC90 } \\
\text { and Nostoc calcicola ISC89 }\end{array}$ & $\begin{array}{l}\text { Harvested biomass-DW was used to } \\
\text { wash the cells. The cell extraction was } \\
\text { carried out by grinding algae with a pestle } \\
\text { and blender in DW. The final extract made } \\
\text { up of } 5.0 \mathrm{~g} \text { fresh algae as the raw material } \\
\text { submerged in } 500 \mathrm{~mL} \text { of DW is assumed to } \\
\text { be a } 1 \% \text { extract }\end{array}$ & $\begin{array}{l}\text { The final extract application was } \\
\text { conducted by spraying the potted } \\
\text { treated soil while the control was } \\
\text { irrigated with water every } 7 \text { days. The } \\
\text { arrangement of pots was a complete } \\
\text { randomized design in a fully } \\
\text { controlled experimental greenhouse. } \\
1 \% \text { extract/spray }\end{array}$ & $\begin{array}{l}\text { The morphological parameters } \\
\text { measured after } 40 \text { days of the } \\
\text { experiment include plant height, } \\
\text { root length, dry and fresh weight of } \\
\text { plant, as well as the number of } \\
\text { leaves }\end{array}$ & [140] \\
\hline
\end{tabular}


Table 6. Cont

\begin{tabular}{|c|c|c|c|c|c|c|}
\hline Crop & Greenhouse & M/Species & Extraction/Process Method & Conc. Of AE & Parameters & Reference \\
\hline Radish & Petri plates & $\begin{array}{l}\text { BGA-Arthrospira platensis } \\
\text { extract }\end{array}$ & $\begin{array}{l}\text { Commercial dried biomass of SP used. } \\
\text { Homogenate }+ \text { centrifugation }= \\
\text { supernatant considered to be } 100 \% \text { algal } \\
\text { filtrate }(1: 10)\end{array}$ & $\begin{array}{c}\text { Foliar spray }(5 \%, 7 \%, 10 \%, 15 \%, 20 \% \text {, } \\
\text { and } 25 \%, v / v) . \\
\text { Seed soaking-dose of } 100,300,500, \\
700 \mu \mathrm{L} \text { per } 1.5 \mathrm{~g} \text { of seed }\end{array}$ & $\begin{array}{c}\text { The longest and heaviest plant was } \\
\text { observed at a dose of } 300 \mu \mathrm{L} / 1.5 \mathrm{~g} \\
\text { seeds and } 15 \% \text { of filtrate as a foliar } \\
\text { application. The chlorophyll content } \\
\text { was higher at } 100 \mu \mathrm{L} / 1.5 \mathrm{~g} \text { seeds as } \\
\text { well as } 5 \% \text { of filtrate as a foliar } \\
\text { application. }\end{array}$ & [122] \\
\hline Rice & $\begin{array}{l}\text { Potted plants } \\
\text { experiment }\end{array}$ & $\begin{array}{c}\text { BGA-Arthrospira maxima } \\
\text { extract }\end{array}$ & $\begin{array}{c}\text { Extracts obtained from three types of } \\
\text { solvent viz. DW, methanol, and hexane at } \\
0,2.5,3.5,4.5 \text {, and } 5 \mathrm{~g} \mathrm{~L}^{-1} \text { of } \\
\text { biomass/solvent }\end{array}$ & $\begin{array}{l}\text { The potted plants were treated with } \\
\text { extracts at three different stages of } \\
\text { seed development, the dry stage, the } \\
\text { radicle emergence stage, and the } \\
\text { vegetative growth stage }\end{array}$ & $\begin{array}{l}\text { DW, methanol, and extracts affect } \\
\text { the germination of seed while } \\
\text { hexane reveals no impact on seed } \\
\text { germination. }\end{array}$ & [145] \\
\hline Wheat seeds & Petri plates & $\begin{array}{c}\text { BGA-Arthrospira platensis } \\
\text { extract }\end{array}$ & $\begin{array}{l}\text { The seeds treated with extract were sown } \\
\text { in a cotton base for the next } 11 \text { days, with } \\
\text { nine replicates of each sample. }\end{array}$ & $\begin{array}{l}\text { The coated seeds in three different } \\
\text { doses }\left(8,14 \text {, and } 20 \mu \mathrm{L} \mathrm{g}^{-1} \text { of seeds) of }\right. \\
\text { formulation were used. Seed coated } \\
\text { with } 8 \mu \mathrm{L} \text { gave the best result }\end{array}$ & $\begin{array}{l}\text { Seeds coated with the extract } \\
\text { resulted in the increase in biomass } \\
\text { yield by approx. 13\% }\end{array}$ & [141] \\
\hline Tomato & Soil & $\begin{array}{l}18 \text { Microalgae and } \\
\text { Cyanobacteria species from } \\
\text { the AlgoBioTech collection }\end{array}$ & Screening of microalgae liquid extracts & $\begin{array}{l}\text { Application doses of } 0.1,0.5 \text {, and } \\
1 \mathrm{~g} \mathrm{~L}^{-1} \text { were tested }\end{array}$ & $\begin{array}{l}\text { The effects on plant growth, } \\
\text { chlorophyll content, and nutrient } \\
\text { uptake were significant }\end{array}$ & [146] \\
\hline Wheat & $\begin{array}{l}\text { Soil } \\
\text { Field trial }\end{array}$ & $\begin{array}{l}\text { Arthrospira plantensis } \\
\text { biomass and extract }\end{array}$ & $\begin{array}{l}\text { As described in the work of Chojnacka } \\
\text { et al. (2014) }\end{array}$ & $\begin{array}{l}\text { Application doses of } 1.0,1.5 \text {, and } 1.8 \mathrm{~L} \\
\text { ha }^{-1} \text { were tested }\end{array}$ & $\begin{array}{l}\text { Quantity of } \\
\text { grains per ear, the quantity of grain, } \\
\text { and shank length }\end{array}$ & [72] \\
\hline Maize & $\begin{array}{l}\text { Soil } \\
\text { Field trial }\end{array}$ & $\begin{array}{l}\text { Laurencia obtuse, Corallina } \\
\text { elongate powder (biomass) }\end{array}$ & $\begin{array}{l}\text { After collection, microalgae were washed, } \\
\text { dried in shadow in the open air, and the } \\
\text { drying process was completed in the oven } \\
\text { at } 60^{\circ} \mathrm{C} \text { for } 5 \mathrm{~h} \text {. The dried biomass was } \\
\text { mechanically ground to the powdery form. }\end{array}$ & $\begin{array}{l}3 \mathrm{~g} \text { of powdered biomass of } \\
\text { microalgae per kg soil. }\end{array}$ & $\begin{array}{l}\text { Root improvement, } \\
\text { Polyphenolic, and antioxidant } \\
\text { contents }\end{array}$ & [142] \\
\hline Cucumber & Soil & $\begin{array}{l}\text { Arthrospira platensis, } \\
\text { Amphora cofeaeformis }\end{array}$ & $\begin{array}{c}\text { Microalgae extracts were prepared as } \\
\text { previously reported by Enan et al. (2016) } \\
\text { [147] }\end{array}$ & $\begin{array}{l}\text { Soil application }-5 \mathrm{~g} \mathrm{~m}^{-2} \\
\text { Foliar application-2 } \mathrm{g} \mathrm{L}^{-1}\end{array}$ & $\begin{array}{l}\text { Vegetative growth, yield, fruit } \\
\text { quality, and nematode control }\end{array}$ & [143] \\
\hline
\end{tabular}




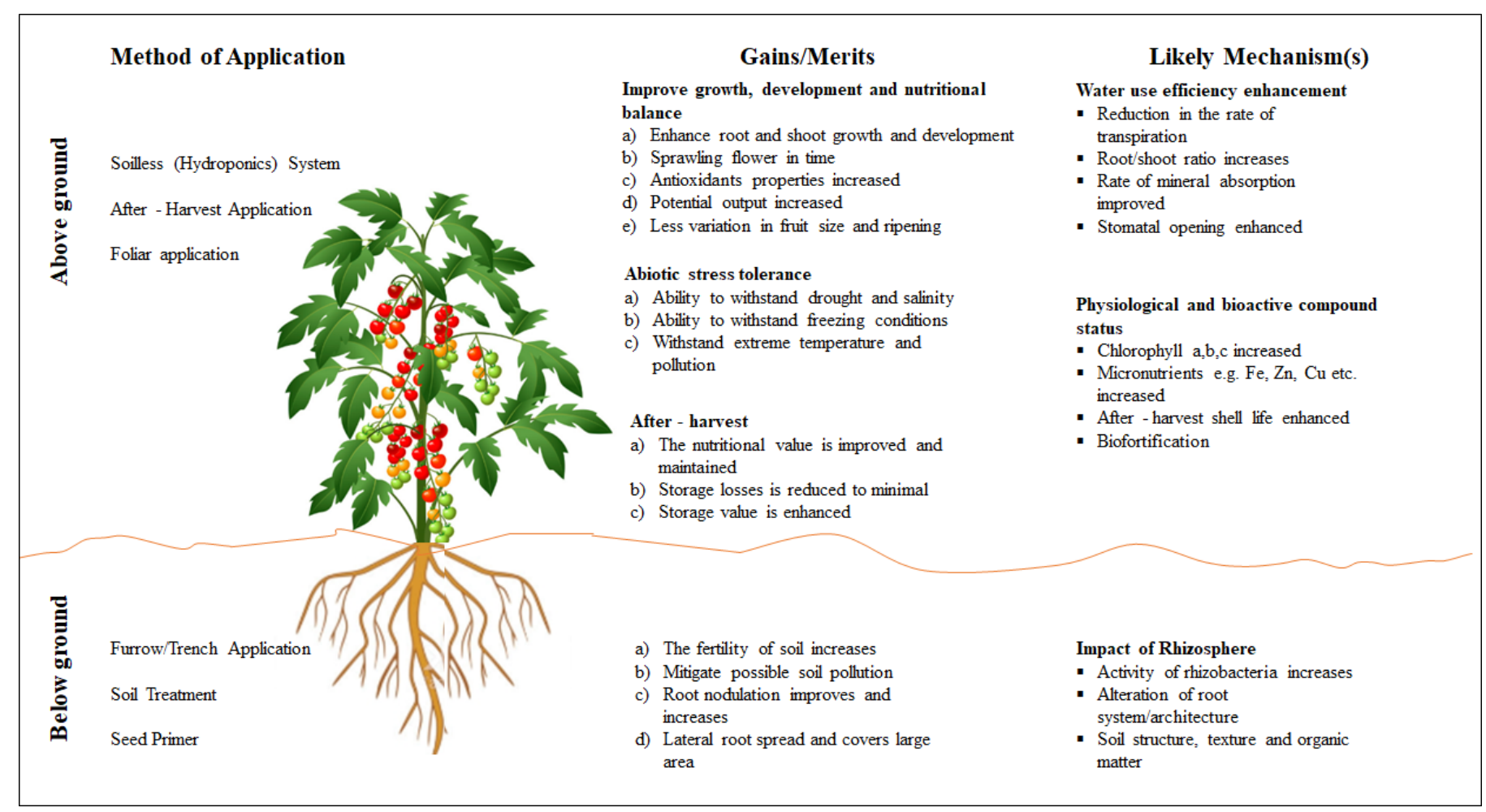

Figure 5. Illustrative diagram showing various application methods of microalgae extract, and their impacts and respective mechanisms of operation on the plant.

\section{As Alleviator of Abiotic Stress}

World climatic changes have contributed immensely to the increase of abiotic stresses on crops, which invariably hinder the growth, development, and output of crops and ultimately reduce world agricultural productivity [148]. Abiotic stresses viz. drought (irregular and erratic rainfall), salinity, excessive heat/extreme temperatures, and waterlogging are peculiar factors responsible for the poor productivity of most crops [149,150]. In recent years, the incidence of abiotic stresses has increased, mainly because of climate change, which has resulted in an unusual rise in severe weather conditions and incidents. Abiotic stresses are responsible for substantial losses of crops around the globe [151]. For instance, climatic change has a negative impact on agricultural production, leading to the losses of nearly USD 220 billion in North America, precisely the USA, as a result of the combination of extreme heat and irregular rainfall (drought) stresses on crops [151]. In Europe, it was estimated that recent annual economic losses as a result of climate change (drought) are amounted to be approximately nine billion euros (EUR 9 billion) for the European Union (EU) and the United Kingdom (UK), respectively. Interestingly, from these losses, between $39 \%$ and $60 \%$ were accounted for by agriculture [152]. Similarly, the situation of the negative impact on agriculture is not different in Asia, Latin America and the Caribbean (LAC), as well as Sub-Saharan Africa, as economic losses were recorded to the tune of USD 42.934 billion, USD 10.023 billion, and USD 14.374 billion, respectively [153]. Biologically active compounds present in the biostimulants enhance the activities and performances of plants suffering from abiotic stresses. The plant output increases, coupled with the correctional measures on the earlier impairments resulting from adverse climatic conditions [154-156]. To achieve an optimal result from using biostimulants as abiotic stress addressor, several conditions must be put in place viz. when to apply the biostimulant on the affected crop (pre, during, and after) and the dosage (concentrations) that needs to be applied most efficiently, as it can pose a dual impact on crop performance [157]. In simi- 
lar experimental testing, microalgae extract application as a biostimulant mitigates high salinity stress in wheat (Triticum aestivum L.) cultivation. The application of extracts from Arthrospira sp. and Chlorella sp. significantly enhances the survival of wheat (T. aestivum L.) under salt stress conditions. An improvement in the whole grains' antioxidant capacity along with protein content was attained due to the anti-salinity potential exhibited by microalgae extracts compared to the control [158].

In the work of Renuka et al., 2018, it was reported that microalgae and cyanobacteria activities may have a great influence either directly or indirectly on the plant improvement in terms of immunity, health, and the potential to withstand any probable negative impacts of the combination of abiotic and biotic stresses [129]. Thus, microalgae species that are characterized by numerous applications to agricultural productivity can be seen as the bio-alternatives to promote agricultural sustainability. Similarly, in a study conducted by El Arrousi et al., 2018, it was indicated that $D$. salina exopolysaccharide reduces the negative impact of multiple levels of salinity in Solanum lycopersicum (tomato) through the incremental increase in the activity of antioxidant enzymes, phenolic compounds, and essential metabolites viz. neophytadiene, tocopherol, stigmasterol, as well as 2,4-ditertbutylphenol, which are regarded as constituents of the major influencer against oxidative stress [137]. Additionally, for instance, Oancea et al., 2013 reported that Nannochloris mitigates the impact of water stress on S. lycopersicum [123].

\section{Future Direction}

Significant developments have been recorded in research on the action mechanisms of microalgae extract-elicited physiological responses, achievable courtesy of advancement in various tools such as "omics" available to modern researchers. Nevertheless, there are several bordering concerns and questions that need to be answered to achieve the best use of microalgae products, as well as their respective extracts in crop cultivation. Such questions include, but are not limited to, the following:

The difficulty in determining the exact stage of the crops when the extracts should be supplied to obtain the maximum positive result. Additionally, it is very challenging to determine the accurate timing and frequency required for the application coupled with the concentration levels to obtain the expected result. As it is, this would call for a more accurate protocol on extract application, either through the soil, foliage, or via other areas of the crop. Furthermore, systematic studies have never been embarked upon to unravel the possible disparity in the physiological response exhibited by the crop at different stages during development.

What is the duration of the effect that the microalgae extract has on the crop after the application at the required concentrations? The ability to establish how long the physiological effect can persist for will invariably assist in determining and planning the rate of microalgae extract applications. Several experimental tests have revealed that different crops respond in a dissimilar way to the concentration and rate of extract application. Consequently, it is essential to establish a more research-oriented plan tailored to specific crops in terms of microalgae application optimization and invariably obtaining a highly significant result.

Although there are numerous studies on the construction and management of ponds for the sustainable production of microalgae, one of the many questions that surround the attainment of optimal production of microalgae is the impact of pond failures, which are yet to be completely understood and thoroughly resolved. Nonetheless, to understand the underlying mechanisms that are perhaps responsible for this, there is a need for research to unravel and subsequently find a preventive measure against it.

Additionally, locally isolated strains from wastewater ponds seem/tend to be more effective from strains obtained from the culture collection, and this should be diligently clarified in future research. Lastly, future research is important to disclose the composition, occurrence, location, and distribution of the target bioactive compounds in microalgae cells, and how to establish a more resilient microalgae population by employing "omic" 
technologies which are primarily concerned with detecting genes (genomics), messenger RNA, mRNA (transcriptomics), proteins (proteomics), and metabolites (metabolomics) in a particular biological sample.

The market-dominated microalgae-extract products are predominantly extracts obtained from the whole microalgae with full strength, and they are considered the first generation of microalgae products. It is necessary to develop more novel microalgae products that will be embedded with precise biostimulant properties. This is achievable if more energy is channeled towards vigorous research on understanding the physiological impacts of specific chemical constituents on various crops.

\section{Conclusions}

In conclusion, extracts from basic materials obtained on a commercial scale from different microalgae are gaining widespread acceptability in agriculture production as plant biostimulants and biofertilizers. Nowadays, different types of extracts are in use extensively, and several commercial agrochemical companies have microalgae extraction and formulation as part of their production lines [156,159]. Interestingly, microalgae extracts obtained from various sources as raw materials pass through different extraction techniques and procedures to produce final products rich in varying degrees of beneficial impacts viz. nutrient intake improvement, increasing the quality of the product, and improving abiotic stress tolerance (Table 6 and Figure 5). Consequently, the application of microalgae extracts is recommended not only as a morphological and physiological enhancer, but also to curtail stressful situations that affect crop growth and development when the need arises with limited negative environmental impact.

Author Contributions: All the listed authors have contributed immensely to the work directly and intellectually with their final consents for publication. All authors have read and agreed to the published version of the manuscript.

Funding: A.S.B. was funded by the Graduate Student Grant (QUST-1-CAS-2020-10) provided by Qatar University. Funds were provided by grant NPRP8-1087-1-207 provided by Qatar National Research Fund (a member of The Qatar Foundation). Open Access funding provided by Qatar University IDC for R.B.H. The statements made herein are solely the responsibility of the authors.

Institutional Review Board Statement: Not applicable.

Informed Consent Statement: Not applicable.

Data Availability Statement: Not applicable.

Conflicts of Interest: The authors declare no conflict of interest.

\section{References}

1. Pelczar, M.J.; Chan, E.C.S.; Krieg, N.R. Microbiology: Concepts and Applications; McGraw-Hill: New York, NY, USA, 1993; Volume 182.

2. Barsanti, L.; Gualtieri, P. Algae: Anatomy, Biochemistry, and Biotechnology; CRC Press: Boca Raton, FL, USA, 2014.

3. Mutanda, T.; Ramesh, D.; Karthikeyan, S.; Kumari, S.; Anandraj, A.; Bux, F. Bioprospecting for hyper-lipid producing microalgal strains for sustainable biofuel production. Bioresour. Technol. 2011, 102, 57-70. [CrossRef] [PubMed]

4. Bellinger, E.G.; Sigee, D.C. Freshwater Algae: Identification, Enumeration and Use as Bioindicators; John Wiley \& Sons: Hoboken, NJ, USA, 2015.

5. Osório, C.; Machado, S.; Peixoto, J.; Bessada, S.; Pimentel, F.B.; Alves, R.C.; Oliveira, M.B.P.P. Pigments Content (Chlorophylls, Fucoxanthin and Phycobiliproteins) of Different Commercial Dried Algae. Separations 2020, 7, 33. [CrossRef]

6. Pereira, T.; Barroso, S.; Mendes, S.; Amaral, R.; Dias, J.R.; Baptista, T.; Saraiva, J.A.; Alves, N.; Gil, M.M. Optimization of phycobiliprotein pigments extraction from red algae Gracilaria gracilis for substitution of synthetic food colorants. Food Chem. 2020, 321, 126688. [CrossRef]

7. Hemaiswarya, S.; Raja, R.; Ravikumar, R.; Carvalho, I.S. Microalgae taxonomy and breeding. In Biofuel Crops: Production, Physiology and Genetics; CABI: Wallingford, UK, 2013; pp. 44-53. [CrossRef]

8. Chapman, D. The Algae; Springer: Berlin/Heidelberg, Germany, 1973.

9. Wehr, J.D.; Sheath, R.G.; Kociolek, J.P. Freshwater Algae of North America: Ecology and Classification; Academic Press: San Diego, CA, USA, 2015. 
10. Suganya, T.; Varman, M.; Masjuki, H.H.; Renganathan, S. Macroalgae and microalgae as a potential source for commercial applications along with biofuels production: A biorefinery approach. Renew. Sustain. Energy Rev. 2016, 55, 909-941. [CrossRef]

11. Candido, C.; Lombardi, A.T. Mixotrophy in green microalgae grown on an organic and nutrient rich waste. World J. Microbiol. Biotechnol. 2020, 36, 20. [CrossRef]

12. Mata, T.M.; Martins, A.; Caetano, N. Microalgae for biodiesel production and other applications: A review. Renew. Sustain. Energy Rev. 2010, 14, 217-232. [CrossRef]

13. Hultberg, M.; Carlsson, A.; Gustafsson, S. Treatment of drainage solution from hydroponic greenhouse production with microalgae. Bioresour. Technol. 2013, 136, 401-406. [CrossRef] [PubMed]

14. Hultberg, M.; Jönsson, H.L.; Bergstrand, K.-J.; Carlsson, A. Impact of light quality on biomass production and fatty acid content in the microalga Chlorella vulgaris. Bioresour. Technol. 2014, 159, 465-467. [CrossRef] [PubMed]

15. Maurya, R.; Paliwal, C.; Ghosh, T.; Pancha, I.; Chokshi, K.; Mitra, M.; Ghosh, A.; Mishra, S. Applications of de-oiled microalgal biomass towards development of sustainable biorefinery. Bioresour. Technol. 2016, 214, 787-796. [CrossRef] [PubMed]

16. Correa, I.; Drews-Jr, P.; Botelho, S.; De Souza, M.S.; Tavano, V.M. Deep Learning for Microalgae Classification. In Proceedings of the 2017 16th IEEE International Conference on Machine Learning and Applications (ICMLA), Cancun, Mexico, 18-21 December 2017; pp. 20-25.

17. Acién, F.G.; Gómez, C.; Morales-Amaral, M.M.; Fernandez, F.G.A.; Molina-Grima, E. Wastewater treatment using microalgae: How realistic a contribution might it be to significant urban wastewater treatment? Appl. Microbiol. Biotechnol. 2016, 100, 9013-9022. [CrossRef]

18. Hossain, N.; Mahlia, T.M.I. Progress in physicochemical parameters of microalgae cultivation for biofuel production. Crit. Rev. Biotechnol. 2019, 39, 835-859. [CrossRef]

19. Lavens, P.; Sorgeloos, P. Manual on the Production and Use of Live Food for Aquaculture; FAO: Rome, Italy, 1993.

20. Richmond, A.; Hu, Q. Handbook of microalgal culture: Applied Phycology and Biotechnology; John Wiley \& Sons: Hoboken, NJ, USA, 2013.

21. FAO. Algal Production-Physical and Chemical Conditions (Culture Medium/Nutrients); FAO: Rome, Italy, 2013.

22. Enzing, C.; Ploeg, M.; Barbosa, M.; Sijtsma, L. Microalgae-Based Products for the Food And Feed Sector: An Outlook for Europe; JRC Scientific and Policy Reports; European Comission: Brussels, Belgium, 2014; pp. 19-37.

23. Becker, E.W. Microalgae: Biotechnology and Microbiology; Cambridge University Press: Cambridge, UK, $1994 ;$ Volume 10.

24. Kaliaperumal, N.; Ramalingam, J.R.; Kalimuthu, S.; Ezhilvalavan, R. Seasonal changes in growth, biochemical constituents and phycocolloid of some marine algae of Mandapam coast. Seaweed Res. Util. 2002, 24, 73-77.

25. Ha, G.-S.; El-Dalatony, M.M.; Kim, D.-H.; Salama, E.-S.; Kurade, M.B.; Roh, H.-S.; Abomohra, A.E.-F.; Jeon, B.-H. Biocomponentbased microalgal transformations into biofuels during the pretreatment and fermentation process. Bioresour. Technol. 2020, 302, 122809. [CrossRef]

26. Machana, K.; Kanokrung, A.; Srichan, S.; Vongsak, B.; Kutako, M.; Siafha, E. Monitoring of Biochemical Compounds and Fatty Acid in Marine Microalgae from the East Coast of Thailand. Walailak J. Sci. Technol. 2018, 17, 334-347. [CrossRef]

27. Zabed, H.M.; Akter, S.; Yun, J.; Zhang, G.; Zhang, Y.; Qi, X. Biogas from microalgae: Technologies, challenges and opportunities. Renew. Sustain. Energy Rev. 2020, 117, 109503. [CrossRef]

28. Priyadarshani, I.; Rath, B. Commercial and industrial applications of micro algae-A review. J. Algal Biomass Util. 2012, 3, 89-100.

29. Chew, K.W.; Yap, J.Y.; Show, P.L.; Suan, N.H.; Juan, J.C.; Ling, T.C.; Lee, D.-J.; Chang, J.-S. Microalgae biorefinery: High value products perspectives. Bioresour. Technol. 2017, 229, 53-62. [CrossRef] [PubMed]

30. Show, P.L.; Tang, M.S.Y.; Nagarajan, D.; Ling, T.C.; Ooi, C.-W.; Chang, J.-S. A Holistic Approach to Managing Microalgae for Biofuel Applications. Int. J. Mol. Sci. 2017, 18, 215. [CrossRef]

31. Petruk, G.; Gifuni, I.; Illiano, A.; Roxo, M.; Pinto, G.; Amoresano, A.; Marzocchella, A.; Piccoli, R.; Wink, M.; Olivieri, G.; et al. Simultaneous production of antioxidants and starch from the microalga Chlorella sorokiniana. Algal Res. 2018, 34, 164-174. [CrossRef]

32. Dasan, Y.K.; Lam, M.K.; Yusup, S.; Lim, J.W.; Lee, K.T. Life cycle evaluation of microalgae biofuels production: Effect of cultivation system on energy, carbon emission and cost balance analysis. Sci. Total Environ. 2019, 688, 112-128. [CrossRef] [PubMed]

33. Yaakob, M.; Mohamed, R.; Al-Gheethi, A.; Ravishankar, G.; Ambati, R. Influence of Nitrogen and Phosphorus on Microalgal Growth, Biomass, Lipid, and Fatty Acid Production: An Overview. Cells 2021, 10, 393. [CrossRef]

34. Roy, S.S.; Pal, R. Microalgae in Aquaculture: A Review with Special References to Nutritional Value and Fish Dietetics. In Proceedings of the Zoological Society; Springer: Berlin/Heidelberg, Germany, 2015; Volume 68, pp. 1-8.

35. Satyanarayana, K.G.; Mariano, A.B.; Vargas, J.V.C. A review on microalgae, a versatile source for sustainable energy and materials. Int. J. Energy Res. 2011, 35, 291-311. [CrossRef]

36. Biller, P.; Ross, A.; Skill, S.; Lea-Langton, A.; Balasundaram, B.; Hall, C.; Riley, R.; Llewellyn, C. Nutrient recycling of aqueous phase for microalgae cultivation from the hydrothermal liquefaction process. Algal Res. 2012, 1, 70-76. [CrossRef]

37. Ajeej, A.; Thanikal, J.V.; Narayanan, C.M.; Kumar, R.S. An overview of bio augmentation of methane by anaerobic co-digestion of municipal sludge along with microalgae and waste paper. Renew. Sustain. Energy Rev. 2015, 50, 270-276. [CrossRef]

38. Demirbas, A.; Demirbas, M.F. Importance of algae oil as a source of biodiesel. Energy Convers. Manag. 2011, 52, 163-170. [CrossRef] 
39. Lee, Y.-K. Microalgal mass culture systems and methods: Their limitation and potential. J. Appl. Phycol. 2001, 13, 307-315. [CrossRef]

40. García, L.M.; Adjallé, K.; Barnabé, S.; Raghavan, G. Microalgae biomass production for a biorefinery system: Recent advances and the way towards sustainability. Renew. Sustain. Energy Rev. 2017, 76, 493-506. [CrossRef]

41. Olaizola, M. Commercial development of microalgal biotechnology: From the test tube to the marketplace. Biomol. Eng. 2003, 20, 459-466. [CrossRef]

42. Junying, Z.; Junfeng, R.; Baoning, Z. Factors in mass cultivation of microalgae for biodiesel. Chin. J. Catal. 2013, $34,80-100$.

43. Carlsson, A.S.; Van Beilen, J.B.; Möller, R.; Clayton, D. Micro-and Macro-Algae: Utility for Industrial Applications; CPL Press: Berkshire, UK, 2007.

44. Costa, J.A.V.; Freitas, B.C.B.; Santos, T.D.; Mitchell, B.G.; de Morais, M.G. Open pond systems for microalgal culture In. Biofuels from Algae; Elsevier: Amsterdam, The Netherlands, 2019; pp. 199-223.

45. Vonshak, A.; Richmond, A. Mass production of the blue-green alga Spirulina: An overview. Biomass 1988, 15, 233-247. [CrossRef]

46. Razzak, S.; Hossain, M.M.; Lucky, R.A.; Bassi, A.S.; de Lasa, H. Integrated $\mathrm{CO}_{2}$ capture, wastewater treatment and biofuel production by microalgae culturing-A review. Renew. Sustain. Energy Rev. 2013, 27, 622-653. [CrossRef]

47. Qin, L.; Alam, A.; Wang, Z. Open Pond Culture Systems and Photobioreactors for Microalgal Biofuel Production. In Microalgae Biotechnology for Development of Biofuel and Wastewater Treatment; Springer: Berlin/Heidelberg, Germany, 2019; pp. 45-74.

48. Benemann, J.R.; Oswald, W.J. Systems and Economic Analysis of Microalgae Ponds For Conversion of CO2 to Biomass; Nasa Sti/recon Technical Report N; US Department of Energy: Washington, DC, USA, 1994; p. 95.

49. Singh, N.K.; Dhar, D.W. Microalgae as second generation biofuel. A review. Agron. Sustain. Dev. 2011, 31, 605-629. [CrossRef]

50. Han, T.; Lu, H.F.; Ma, S.S.; Zhang, Y.H.; Liu, Z.D.; Duan, N. Progress in microalgae cultivation photobioreactors and applications in wastewater treatment: A review. Int. J. Agric. Biol. Eng. 2017, 10, 1-29.

51. Chew, K.W.; Chia, S.R.; Show, P.L.; Yap, Y.J.; Ling, T.C.; Chang, J.-S. Effects of water culture medium, cultivation systems and growth modes for microalgae cultivation: A review. J. Taiwan Inst. Chem. Eng. 2018, 91, 332-344. [CrossRef]

52. Tredici, M.R. Mass production of microalgae: Photobioreactors. In Handbook of Microalgal Culture: Biotechnology and Applied Phycology; Wiley-Blackwell: Hoboken, NJ, USA, 2004; Volume 1, pp. 178-214.

53. Pulz, O. Photobioreactors: Production systems for phototrophic microorganisms. Appl. Microbiol. Biotechnol. 2001, 57, 287-293. [PubMed]

54. Chisti, Y. Biodiesel from microalgae. Biotechnol. Adv. 2007, 25, 294-306. [CrossRef] [PubMed]

55. Singh, R.; Sharma, S. Development of suitable photobioreactor for algae production-A review. Renew. Sustain. Energy Rev. 2012, 16, 2347-2353. [CrossRef]

56. Janssen, M.; Tramper, J.; Mur, L.R. Enclosed outdoor photobioreactors: Light regime, photosynthetic efficiency, scale-up, and future prospects. Biotechnol. Bioeng. 2002, 81, 193-210. [CrossRef]

57. Brennan, L.; Owende, P. Biofuels from microalgae-A review of technologies for production, processing, and extractions of biofuels and co-products. Renew. Sustain. Energy Rev. 2010, 14, 557-577. [CrossRef]

58. Vasumathi, K.; Premalatha, M.; Subramanian, P. Parameters influencing the design of photobioreactor for the growth of microalgae. Renew. Sustain. Energy Rev. 2012, 16, 5443-5450. [CrossRef]

59. Wang, B.; Lan, C.Q.; Horsman, M. Closed photobioreactors for production of microalgal biomasses. Biotechnol. Adv. 2012, 30, 904-912. [CrossRef]

60. Aishvarya, V.; Pradhan, N.; Nayak, R.R.; Sukla, L.B.; Mishra, B.K. Enhanced inorganic carbon uptake by Chlorella sp. IMMTCC-2 under autotrophic conditions for lipid production and $\mathrm{CO}_{2}$ sequestration. Environ. Biol. Fishes 2012, 24, 1455-1463. [CrossRef]

61. Slegers, P.; Lösing, M.; Wijffels, R.; van Straten, G.; van Boxtel, A. Scenario evaluation of open pond microalgae production. Algal Res. 2013, 2, 358-368. [CrossRef]

62. Harun, R.; Singh, M.; Forde, G.M.; Danquah, M.K. Bioprocess engineering of microalgae to produce a variety of consumer products. Renew. Sustain. Energy Rev. 2010, 14, 1037-1047. [CrossRef]

63. Barbosa, M.J.; Albrecht, M. Hydrodynamic stress and lethal events in sparged microalgae cultures. Biotechnol. Bioeng. 2003, 83, 112-120. [CrossRef] [PubMed]

64. Pires, J.; Alvim-Ferraz, M.D.C.; Martins, F. Photobioreactor design for microalgae production through computational fluid dynamics: A review. Renew. Sustain. Energy Rev. 2017, 79, 248-254. [CrossRef]

65. Eriksen, N.T. The technology of microalgal culturing. Biotechnol. Lett. 2008, 30, 1525-1536. [CrossRef]

66. Das, P.; Aziz, S.S.; Obbard, J.P. Two phase microalgae growth in the open system for enhanced lipid productivity. Renew. Energy 2011, 36, 2524-2528. [CrossRef]

67. Suali, E.; Sarbatly, R. Conversion of microalgae to biofuel. Renew. Sustain. Energy Rev. 2012, 16, 4316-4342. [CrossRef]

68. Norsker, N.-H.; Barbosa, M.J.; Vermuë, M.H.; Wijffels, R.H. Microalgal production-A close look at the economics. Biotechnol. Adv. 2011, 29, 24-27. [CrossRef] [PubMed]

69. Acién, F.; Molina, E.; Reis, A.; Torzillo, G.; Zittelli, G.; Sepúlveda, C.; Masojídek, J. Photobioreactors for the production of microalgae. In Microalgae-Based Biofuels and Bioproducts; Elsevier BV: Amsterdam, The Netherlands, 2017; pp. 1-44.

70. Suparmaniam, U.; Lam, M.K.; Uemura, Y.; Lim, J.W.; Lee, K.T.; Shuit, S.H. Insights into the microalgae cultivation technology and harvesting process for biofuel production: A review. Renew. Sustain. Energy Rev. 2019, 115, 109361. [CrossRef] 
71. Khan, W.; Rayirath, U.P.; Subramanian, S.; Jithesh, M.N.; Rayorath, P.; Hodges, D.M.; Critchley, A.; Craigie, J.S.; Norrie, J.; Prithiviraj, B. Seaweed Extracts as Biostimulants of Plant Growth and Development. J. Plant Growth Regul. 2009, 28, 386-399. [CrossRef]

72. Michalak, I.; Chojnacka, K.; Dmytryk, A.; Wilk, R.; Gramza, M.; Rój, E. Evaluation of Supercritical Extracts of Algae as Biostimulants of Plant Growth in Field Trials. Front. Plant Sci. 2016, 7, 1591. [CrossRef]

73. Spolaore, P.; Joannis-Cassan, C.; Duran, E.; Isambert, A. Commercial applications of microalgae. J. Biosci. Bioeng. 2006, 101, 87-96. [CrossRef]

74. Gupta, S.; Abu-Ghannam, N. Bioactive potential and possible health effects of edible brown seaweeds. Trends Food Sci. Technol. 2011, 22, 315-326. [CrossRef]

75. Gupta, S.; Abu-Ghannam, N. Recent developments in the application of seaweeds or seaweed extracts as a means for enhancing the safety and quality attributes of foods. Innov. Food Sci. Emerg. Technol. 2011, 12, 600-609. [CrossRef]

76. Lafarga, T. Cultured Microalgae and Compounds Derived Thereof for Food Applications: Strain Selection and Cultivation, Drying, and Processing Strategies. Food Rev. Int. 2020, 36, 559-583. [CrossRef]

77. Subashini, G.; Bhuvaneswari, S. Novel Products from Microalgae. In Bioactive Natural Products in Drug Discovery; Springer: Berlin/Heidelberg, Germany, 2020; pp. 451-465.

78. Samarasinghe, N.; Fernando, S.; Faulkner, W.B. Effect of high pressure homogenization on aqueous phase solvent extraction of lipids from Nannochloris oculata microalgae. J. Energy Nat. Resour. 2012, 1, 1-7. [CrossRef]

79. Chiaiese, P.; Corrado, G.; Colla, G.; Kyriacou, M.; Rouphael, Y. Renewable Sources of Plant Biostimulation: Microalgae as a Sustainable Means to Improve Crop Performance. Front. Plant Sci. 2018, 9, 1782. [CrossRef]

80. Michalak, I.; Chojnacka, K. Algal extracts: Technology and advances. Eng. Life Sci. 2014, 14, 581-591. [CrossRef]

81. Michalak, I.; Chojnacka, K. Algae as production systems of bioactive compounds. Eng. Life Sci. 2015, 15, 160-176. [CrossRef]

82. Ramluckan, K.; Moodley, K.G.; Bux, F. An evaluation of the efficacy of using selected solvents for the extraction of lipids from algal biomass by the soxhlet extraction method. Fuel 2014, 116, 103-108. [CrossRef]

83. Ibañez, E.; Herrero, M.; Mendiola, J.A.; Castro-Puyana, M. Extraction and Characterization of Bioactive Compounds with Health Benefits from Marine Resources: Macro and Micro Algae, Cyanobacteria, and Invertebrates. In Marine Bioactive Compounds; Hayes, M., Ed.; Springer: Berlin/Heidelberg, Germany, 2012; pp. 55-98.

84. Kadam, S.; Tiwari, B.K.; O’Donnell, C. Application of Novel Extraction Technologies for Bioactives from Marine Algae. J. Agric. Food Chem. 2013, 61, 4667-4675. [CrossRef] [PubMed]

85. Sovova, H. Steps of supercritical fluid extraction of natural products and their characteristic times. J. Supercrit. Fluids 2012, 66, 73-79. [CrossRef]

86. Herrero, M.; Sánchez-Camargo, A.D.P.; Cifuentes, A.; Ibáñez, E. Plants, seaweeds, microalgae and food by-products as natural sources of functional ingredients obtained using pressurized liquid extraction and supercritical fluid extraction. TrAC Trends Anal. Chem. 2015, 71, 26-38. [CrossRef]

87. Zinnai, A.; Sanmartin, C.; Taglieri, I.; Andrich, G.; Venturi, F. Supercritical fluid extraction from microalgae with high content of LC-PUFAs. A case of study: Sc-CO ${ }_{2}$ oil extraction from Schizochytrium sp. J. Supercrit. Fluids 2016, 116, 126-131. [CrossRef]

88. Herrero, M.; Cifuentes, A.; Ibanez, E. Sub- and supercritical fluid extraction of functional ingredients from different natural sources: Plants, food-by-products, algae and microalgae: A review. Food Chem. 2006, 98, 136-148. [CrossRef]

89. Mendiola, J.A.; Santoyo, S.; Cifuentes, A.; Reglero, G.; Ibanez, E.; Señoráns, F.J. Antimicrobial Activity of Sub- and Supercritical $\mathrm{CO}_{2}$ Extracts of the Green Alga Dunaliella salina. J. Food Prot. 2008, 71, 2138-2143. [CrossRef]

90. Steytler, D. Supercritical fluid extraction and its application in the food industry. In Separation Processes in the Food and Biotechnology Industries: Principles and Applications; Woodhead Publishing: Sawston, UK, 1996; p. 17.

91. Schütz, E. Supercritical fluids and applications-A patent review. In Chemical Engineering E Technology: Industrial Chemistry-Plant Equipment-Process Engineering-Biotechnology; Wiley-VCH GmbH: Weinheim, Germany, 2007; Volume 6, pp. 685-688.

92. Herrero, M.; Mendiola, J.A.; Cifuentes, A.; Ibanez, E. Supercritical fluid extraction: Recent advances and applications. J. Chromatogr. A 2010, 1217, 2495-2511. [CrossRef] [PubMed]

93. Richter, B.; Jones, B.A.; Ezzell, A.J.L.; Porter, N.L.; Avdalovic, N.; Pohl, C. Accelerated Solvent Extraction: A Technique for Sample Preparation. Anal. Chem. 1996, 68, 1033-1039. [CrossRef]

94. Nieto, A.; Borrull, F.; Pocurull, E.; Marcé-Recasens, R.M. Pressurized liquid extraction: A useful technique to extract pharmaceuticals and personal-care products from sewage sludge. TrAC Trends Anal. Chem. 2010, 29, 752-764. [CrossRef]

95. Shang, Y.F.; Kim, S.M.; Lee, W.J.; Um, B.-H. Pressurized liquid method for fucoxanthin extraction from Eisenia bicyclis (Kjellman) Setchell. J. Biosci. Bioeng. 2011, 111, 237-241. [CrossRef] [PubMed]

96. Koo, S.Y.; Cha, K.H.; Song, D.-G.; Chung, D.; Pan, C.-H. Optimization of pressurized liquid extraction of zeaxanthin from Chlorella ellipsoidea. Environ. Biol. Fishes 2011, 24, 725-730. [CrossRef]

97. Ganzler, K.; Salgó, A.; Valkó, K. Microwave extraction: A novel sample preparation method for chromatography. J. Chromatogr. A 1986, 371, 299-306. [CrossRef]

98. Ohring, M.; Kasprzak, L. Reliability and Failure of Electronic Materials and Devices; Elsevier: Amsterdam, The Netherlands, 2015.

99. Ying, Z.; Han, X.; Li, J. Ultrasound-assisted extraction of polysaccharides from mulberry leaves. Food Chem. 2011, 127, 1273-1279. [CrossRef] 
100. Routray, W.; Orsat, V. Microwave-Assisted Extraction of Flavonoids: A Review. Food Bioprocess Technol. $2011,5,409-424$. [CrossRef]

101. Cravotto, G.; Boffa, L.; Mantegna, S.; Perego, P.; Avogadro, M.; Cintas, P. Improved extraction of vegetable oils under high-intensity ultrasound and/or microwaves. Ultrason. Sonochem. 2008, 15, 898-902. [CrossRef]

102. Pasquet, V.; Chérouvrier, J.-R.; Farhat, F.; Thiéry, V.; Piot, J.M.; Bérard, J.-B.; Kaas, R.; Serive, B.; Patrice, T.; Cadoret, J.-P.; et al Study on the microalgal pigments extraction process: Performance of microwave assisted extraction. Process. Biochem. 2011, 46, 59-67. [CrossRef]

103. Rodriguez-Jasso, R.M.; Mussatto, S.I.; Pastrana, L.; Aguilar, C.N.; Teixeira, J.A. Microwave-assisted extraction of sulfated polysaccharides (fucoidan) from brown seaweed. Carbohydrate. Polymers 2011, 86, 1137-1144.

104. Wang, B.; Tong, G.Z.; Le Qu, Y.; Li, L. Microwave-Assisted Extraction and In Vitro Antioxidant Evaluation of Polysaccharides from Enteromorpha prolifera. Appl. Mech. Mater. 2011, 79, 204-209. [CrossRef]

105. Li, Z.; Wang, B.; Zhang, Q.; Qu, Y.; Xu, H.; Li, G. Preparation and antioxidant property of extract and semipurified fractions of Caulerpa racemosa. Environ. Biol. Fishes 2012, 24, 1527-1536. [CrossRef]

106. Xiao, X.; Si, X.; Yuan, Z.; Xu, X.; Li, G. Isolation of fucoxanthin from edible brown algae by microwave-assisted extraction coupled with high-speed countercurrent chromatography. J. Sep. Sci. 2012, 35, 2313-2317. [CrossRef]

107. Klejdus, B.; Lojková, L.; Plaza, M.; Šnóblová, M.; Štěrbová, D. Hyphenated technique for the extraction and determination of isoflavones in algae: Ultrasound-assisted supercritical fluid extraction followed by fast chromatography with tandem mass spectrometry. J. Chromatogr. A 2010, 1217, 7956-7965. [CrossRef] [PubMed]

108. Jeon, Y.-J.; Wijesinghe, W.A.J.P. Enzyme-Assisted Extraction and Recovery of Bioactive Components from Seaweeds; John Wiley \& Sons, Ltd.: Hoboken, NJ, USA, 2011; pp. 221-228. [CrossRef]

109. Liang, K.; Zhang, Q.; Cong, W. Enzyme-Assisted Aqueous Extraction of Lipid from Microalgae. J. Agric. Food Chem. 2012, 60, 11771-11776. [CrossRef]

110. Puglisi, I.; Barone, V.; Sidella, S.; Coppa, M.; Broccanello, C.; Gennari, M.; Baglieri, A. Biostimulant activity of humic-like substances from agro-industrial waste on Chlorella vulgaris and Scenedesmus quadricauda. Eur. J. Phycol. 2018, 53, 433-442. [CrossRef]

111. Shuping, Z.; Yulong, W.; Mingde, Y.; Kaleem, I.; Chun, L.; Tong, J. Production and characterization of bio-oil from hydrothermal liquefaction of microalgae Dunaliella tertiolecta cake. Energy 2010, 35, 5406-5411. [CrossRef]

112. Maddi, B.; Viamajala, S.; Varanasi, S. Comparative study of pyrolysis of algal biomass from natural lake blooms with lignocellulosic biomass. Bioresour. Technol. 2011, 102, 11018-11026. [CrossRef]

113. Anand, V.; Gautam, R.; Vinu, R. Non-catalytic and catalytic fast pyrolysis of Schizochytrium limacinum microalga. Fuel 2017, 205, 1-10. [CrossRef]

114. Li, B.; Yang, L.; Wang, C.-Q.; Zhang, Q.-P.; Liu, Q.-C.; Li, Y.-D.; Xiao, R. Adsorption of Cd(II) from aqueous solutions by rape straw biochar derived from different modification processes. Chemosphere 2017, 175, 332-340. [CrossRef] [PubMed]

115. Andrade, L.; Batista, F.; Lira, T.; Barrozo, M.; Vieira, L. Characterization and product formation during the catalytic and non-catalytic pyrolysis of the green microalgae Chlamydomonas reinhardtii. Renew. Energy 2017, 119, 731-740. [CrossRef]

116. Yang, C.; Li, R.; Zhang, B.; Qiu, Q.; Wang, B.; Yang, H.; Ding, Y.; Wang, C. Pyrolysis of microalgae: A critical review. Fuel Process. Technol. 2019, 186, 53-72. [CrossRef]

117. Becker, E. Microalgae for Human and Animal Nutrition. In Handbook of Microalgae Culture: Applied Phycology and Biotechnology, 2nd ed.; Wiley Blackwell: Hoboken, NJ, USA, 2013; pp. 461-503.

118. Colla, G.; Svecova, E.B.; Cardarelli, M.; Rouphael, Y.; Reynaud, H.; Canaguier, R.; Planques, B. Effectiveness of a plant-derived protein hydrolysate to improve crop performances under different growing conditions. Acta Hortic. 2013, 175-179. [CrossRef]

119. Colla, G.; Rouphael, Y.; Canaguier, R.; Svecova, E.B.; Cardarelli, M. Biostimulant action of a plant-derived protein hydrolysate produced through enzymatic hydrolysis. Front. Plant Sci. 2014, 5, 448. [CrossRef] [PubMed]

120. Colla, G.; Rouphael, Y.; Lucini, L.; Canaguier, R.; Stefanoni, W.; Fiorillo, A.; Cardarelli, M. Protein hydrolysate-based biostimulants: Origin, biological activity and application methods. Acta Hortic. 2016, 1148, 27-34. [CrossRef]

121. Bhalamurugan, G.L.; Valerie, O.; Mark, L. Valuable bioproducts obtained from microalgal biomass and their commercial applications: A review. Environ. Eng. Res. 2018, 23, 229-241. [CrossRef]

122. Godlewska, K.; Michalak, I.; Pacyga, P.; Baśladyńska, S.; Chojnacka, K. Potential applications of cyanobacteria: Spirulina platensis filtrates and homogenates in agriculture. World J. Microbiol. Biotechnol. 2019, 35, 80. [CrossRef]

123. Oancea, F.; Velea, S.; Fãtu, V.; Mincea, C.; Ilie, L. Microalgae-based plant biostimulant and its effect on water stressed tomato plants. Rom. J. Plant Prot. 2013, 6, 104-117.

124. Dias, G.A.; Rocha, R.H.C.; Araújo, J.L.; Lima, J.F.; Guedes, W.A. Growth, yield, and postharvest quality in eggplant produced under different foliar fertilizer (Spirulina platensis) treatments. Semina 2016, 37, 3893. [CrossRef]

125. Garcia-Gonzalez, J.; Sommerfeld, M.R. Biofertilizer and biostimulant properties of the microalga Acutodesmus dimorphus. Environ. Biol. Fishes 2015, 28, 1051-1061. [CrossRef] [PubMed]

126. Plaza, B.M.; Gómez-Serrano, C.; Fernandez, F.G.A.; Jimenez-Becker, S. Effect of microalgae hydrolysate foliar application (Arthrospira platensis and Scenedesmus sp.) on Petunia $\times$ hybrida growth. Environ. Biol. Fishes 2018, 30, 2359-2365. [CrossRef]

127. Berry, Z.C.; Emery, N.C.; Gotsch, S.G.; Goldsmith, G.R. Foliar water uptake: Processes, pathways, and integration into plant water budgets. Plant. Cell Environ. 2018, 42, 410-423. [CrossRef] [PubMed] 
128. Coppens, J.; Grunert, O.; Hende, S.V.D.; Vanhoutte, I.; Boon, N.; Haesaert, G.; De Gelder, L. The use of microalgae as a high-value organic slow-release fertilizer results in tomatoes with increased carotenoid and sugar levels. Environ. Biol. Fishes 2015, 28, 2367-2377. [CrossRef]

129. Renuka, N.; Guldhe, A.; Prasanna, R.; Singh, P.; Bux, F. Microalgae as multi-functional options in modern agriculture: Current trends, prospects and challenges. Biotechnol. Adv. 2018, 36, 1255-1273. [CrossRef] [PubMed]

130. De Morais, M.G.; Vaz, B.D.S.; de Morais, E.G.; Costa, J.A.V. Biologically active metabolites synthesized by microalgae. BioMed Res. Int. 2015, 2015, 835761. [CrossRef] [PubMed]

131. Borowitzka, M. Chemically-Mediated Interactions in Microalgae; Springer: Berlin/Heidelberg, Germany, 2016; pp. 321-357. [CrossRef]

132. Paudel, Y.; Pradhan, S.; Pant, B.; Prasad, B.N. Role of blue green algae in rice productivity. Agric. Biol. J. N. Am. 2012, 3, 332-335. [CrossRef]

133. Shalaby, T.A.; El-Ramady, H. Effect of foliar application of bio-stimulants on growth, yield, components, and storability of garlic ('Allium sativum' L.). Aust. J. Crop. Sci. 2014, 8, 271.

134. Tarraf, S.A.; Talaat, I.M.; El-Sayed, A.E.-K.B.; Balbaa, L.K. Influence of foliar application of algae extract and amino acids mixture on fenugreek plants in sandy and clay soils. Nusant. Biosci. 1970, 7, 33-37. [CrossRef]

135. Lee, X.J.; Ong, H.C.; Gan, Y.Y.; Chen, W.-H.; Mahlia, T.M.I. State of art review on conventional and advanced pyrolysis of macroalgae and microalgae for biochar, bio-oil and bio-syngas production. Energy Convers. Manag. 2020, 210, 112707. [CrossRef]

136. Zhang, J.; Wang, X.; Zhou, Q. Co-cultivation of Chlorella spp and tomato in a hydroponic system. Biomass Bioenergy 2017, 97, 132-138. [CrossRef]

137. EL Arroussi, H.; Benhima, R.; Elbaouchi, A.; Sijilmassi, B.; EL Mernissi, N.; Aafsar, A.; Meftah-Kadmiri, I.; Bendaou, N.; Smouni, A. Dunaliella salina exopolysaccharides: A promising biostimulant for salt stress tolerance in tomato (Solanum lycopersicum). Environ. Biol. Fishes 2018, 30, 2929-2941. [CrossRef]

138. Faheed, F.A.; Fattah, Z.A. Effect of Chlorella vulgaris as bio-fertilizer on growth parameters and metabolic aspects of lettuce plant. J. Agric. Soc. Sci. 2008, 4, 165-169.

139. Barone, V.; Baglieri, A.; Stevanato, P.; Broccanello, C.; Bertoldo, G.; Bertaggia, M.; Cagnin, M.; Pizzeghello, D.; Moliterni, V.M.C.; Mandolino, G.; et al. Root morphological and molecular responses induced by microalgae extracts in sugar beet (Beta vulgaris L.). Environ. Biol. Fishes 2017, 30, 1061-1071. [CrossRef]

140. Shariatmadari, Z.; Riahi, H.; Hashtroudi, M.S.; Ghassempour, A.; Aghashariatmadary, Z. Plant growth promoting cyanobacteria and their distribution in terrestrial habitats of Iran. Soil Sci. Plant Nutr. 2013, 59, 535-547. [CrossRef]

141. Dmytryk, A.; Roj, E.; Wilk, R.; Chojnacka, K. Innovative bioformulations for seed treatment. Preliminary assessment of functional properties in the initial plant growth phase. Przem. Chem. 2014, 93, 959-963.

142. Al-Saman, M.A.; Farfour, S.A.; Hamouda, R.A. Effects of some red Algae on antioxidant and phytochemical contents of Maize (Zea mays L.) plants. Int. J. Agric. 2015, 5, 393-398.

143. El-Eslamboly, A.A.S.A.; El-Wanis, M.M.A.; Amin, A.W. Algal application as a biological control method of root-knot nematode Meloidogyne incognita on cucumber under protected culture conditions and its impact on yield and fruit quality. Egypt. J. Biol. Pest Control 2019, 29, 18. [CrossRef]

144. Wuang, S.C.; Khin, M.C.; Chua, P.Q.D.; Luo, Y.D. Use of Spirulina biomass produced from treatment of aquaculture wastewater as agricultural fertilizers. Algal Res. 2016, 15, 59-64. [CrossRef]

145. Sornchai, P.; Saithong, N.; Srichompoo, Y.; Unartngam, A.; Iamtham, S. Effect of Spirulina maxima aqueous extract on seed germination and seedling growth of mung bean, Vigna radiata and rice, Oryza sativa var. Japonica. J. ISSAAS 2014, 20, 77-84.

146. Chanda, M.-J.; Redouane, B.; Najib, E.; Yassine, K.; Lyamlouli, K.; Laila, S.; Zeroual, Y. Screening of microalgae liquid extracts for their bio stimulant properties on plant growth, nutrient uptake and metabolite profile of Solanum lycopersicum L. Sci. Rep. 2020, 10, 2820.

147. Enan, S.A.A.M.; El-Saady, A.M.; El-Sayed, A.B. Impact of foliar feeding with alga extract and boron on yield and quality of sugar beet grown in sandy soil. Egypt J. Agronematol. 2016, 38, 319-336.

148. Meena, K.K.; Sorty, A.M.; Bitla, U.M.; Choudhary, K.; Gupta, P.; Pareek, A.; Singh, D.P.; Prabha, R.; Sahu, P.K.; Gupta, V.K.; et al. Abiotic Stress Responses and Microbe-Mediated Mitigation in Plants: The Omics Strategies. Front. Plant Sci. 2017, 8, 172. [CrossRef]

149. Suzuki, N. Hormone signaling pathways under stress combinations. Plant Signal. Behav. 2016, 11, e1247139. [CrossRef] [PubMed]

150. Bilal, S.; Shahzad, R.; Imran, M.; Jan, R.; Kim, K.M.; Lee, I.-J. Synergistic association of endophytic fungi enhances Glycine max L. resilience to combined abiotic stresses: Heavy metals, high temperature and drought stress. Ind. Crop. Prod. 2020, $143,111931$. [CrossRef]

151. Lamaoui, M.; Jemo, M.; Datla, R.; Bekkaoui, F. Heat and Drought Stresses in Crops and Approaches for Their Mitigation. Front. Chem. 2018, 6, 26. [CrossRef]

152. Cammalleri, C.; Naumann, G.; Mentaschi, L.; Formetta, G.; Forzieri, G.; Gosling, S.; Bisselink, B.; De Roo, A.; Feyen, L. Global Warming and Drought Impacts in the EU; European Comission: Brussels, Belgium, 2020.

153. FAO. Damage and Losses from Climate-Related Disasters in Agricultural Sectors; FAO: Rome, Italy, 2016. Available online: http: //www.fao.org/3/i6486e/i6486e.pdf (accessed on 6 July 2021).

154. Calvo, P.; Nelson, L.; Kloepper, J.W. Agricultural uses of plant biostimulants. Plant Soil 2014, 383, 3-41. [CrossRef] 
155. Van Oosten, M.J.; Pepe, O.; De Pascale, S.; Silletti, S.; Maggio, A. The role of biostimulants and bioeffectors as alleviators of abiotic stress in crop plants. Chem. Biol. Technol. Agric. 2017, 4, 5. [CrossRef]

156. Ronga, D.; Biazzi, E.; Parati, K.; Carminati, D.; Carminati, E.; Tava, A. Microalgal Biostimulants and Biofertilisers in Crop Productions. Agronomy 2019, 9, 192. [CrossRef]

157. Vernieri, P.; Pepe, O.; De Pascale, S.; Silletti, S.; Maggio, A. Application of biostimulants in floating system for improving rocket quality. J. Food Agric. Environ. 2005, 3, 86.

158. Abd El-Baky, H.H.; El-Baz, F.K.; El Baroty, G.S. Enhancing antioxidant availability in wheat grains from plants grown under seawater stress in response to microalgae extract treatments. J. Sci. Food Agric. 2010, 90, 299-303. [CrossRef] [PubMed]

159. Colla, G.; Rouphael, Y. Microalgae: New Source of Plant Biostimulants. Agronomy 2020, 10, 1240. [CrossRef] 